\title{
Fundamental Causes of Inland-coastal Income Inequality in Post-reform China
}

\author{
Rui $\mathrm{HAO}^{\mathrm{a}}$ and Zheng $\mathrm{WEI}^{\mathrm{b}}$ \\ ${ }^{\text {a }}$ Corresponding author \\ CERDI, Université d'Auvergne, 65 Boulevard François Mitterrand \\ 63000 Clermont-Ferrand, France. Email: rui.hao@u-clermont1.fr \\ ${ }^{\mathrm{b}}$ Department of Economics, University of Birmingham, Edgbaston \\ Birmingham, B15 2TT, U.K. Email: zxw245@bham.ac.uk
}

Preliminary draft: December 2007

\begin{abstract}
This paper investigates the fundamental causes of the widening inland-coastal inequality in China during the reform period 1978-2004 within a systematic framework of economic development theory. We highlight the roles of three policy variables, namely globalization, decentralization and marketization, in determining the income gap between inland and coastal regions. The results derived from both time-series and panel data provide strong evidence that these policies are thus far inequality-enhancing. This finding is robust to the use of different estimation methods, alternative proxies for policies and regional income, and the inclusion of other controls. We also find significant but economically small spillover effects from the coastal to inland provinces. Our results suggest that more efforts should be made to improve the policies to reduce regional inequality in China.
\end{abstract}

Keywords: inland-coastal inequality, globalization, decentralization, marketization JEL classification: O15, O18, R58 


\section{Fundamental Causes of Inland-coastal Income Inequality in Post-reform China}

\section{Introduction}

Regional inequality in China, especially between inland and coastal regions, has risen so dramatically since the 1978 reform that it becomes a very important issue for academic inquiry. Scholars have long disagreed over the sources of growing regional inequality. Empirical evidence also tends to be mixed. A large number of factors were found to be responsible for regional inequality, but the question remains: what are the very fundamental causes?

Economic development theories have highlighted the fundamental roles of geography, integration and institutions in determining income levels of the economies (Rodrik et al., 2004, see Fig.1). Likewise, differences in these three factors explain the income disparities among different economies. China is a large country with long-lasting uneven regional development. China's coastal areas have always been ahead of the inland in terms of development and modernization. Geography plays a role in producing such regional differences via three channels. First, compared with coastal region, inland regions have less favorable natural conditions for agricultural production such as saline soil, high elevation and severe climate. The rugged physical conditions also increase the costs of infrastructure and industrial development. Second, the distance limits the access to seaports and international market for inland regions. Third, geography also affects development through its effects on the access to education and knowledge spillover, flows of productive resources and spatial clustering, as well as institutional reform and effective implementation of government policy, as suggested by the literature of the new economic geography (Krugman, 1995; Sachs et al., 2000).

However, the geographical advantages of the coastal region were not realized until the economic reforms launched in 1978 (Bao et al., 2002). As Fig.1 shows, integration and institutions are considered to be the endogenous fundamental determinants of income. Within the context of Chinese economy, both integration into the global economy and changes in institutions are largely driven by the government policies. Since 1978, the Chinese government has put much emphasis on opening up to the outside world, decentralization in economic decision-making and market-oriented reforms. These policies promoted rapid growth in the coastal areas, but had far less impacts on the inland provinces. As a result, the gap between inland and coastal regions widened continuously and experienced a sharp rise in the 1990s. The inland-coastal inequality has become the largest contributor to the overall regional inequality.

In this paper, we highlighted the role of three policy variables, namely globalization, decentralization and marketization, in exploring the deep-rooted causes of the income gap between inland and coastal regions in post-reform China. While these three variables have strongly influenced regional development in China, they are either neglected or studied in an indirect way. We directly estimate the contributions of these three policy variables on the inland-coastal income inequality. It should be noted the actual effects of the policy variables on income inequality rely not only on the policy design and intentions of the central government, but the policy responses from other agents as well. With the market economy being increasingly established, central government's policies cannot straightforwardly reach the bottom level of the economy. Localities, domestic and global investors have emerged as 
important agents in shaping China's regional inequality (Wei, 2002).

The empirical results derived from both time-series and panel data provide strong evidence that these policies are thus far inequality-enhancing, even when the endogeneity and the fixed effects (mainly geography) are controlled for. This finding turns to be quite robust to the use of different estimation methods, alternative proxies for policies and regional income, and the inclusion of other controls. Furthermore, we find significant but economically small spillover effects from the coastal to inland provinces. While acknowledging the policy determinants, we find that geographical factors also play a significant role in determining the inland-coastal inequality.

The paper is organized as follows. Section 2 reviews the studies on China's regional inequality. Section 3 presents the evolution of regional inequality in China, with a particular focus on the rapidly growing inland-coastal inequality during the reform period. Section 4 describes the theoretical arguments on the regional implications of the three policy variables. Section 5 provides empirical evidence from both time series and panel data estimations. Finally, Section 6 concludes.

Fig.1: The fundamental determinants of income

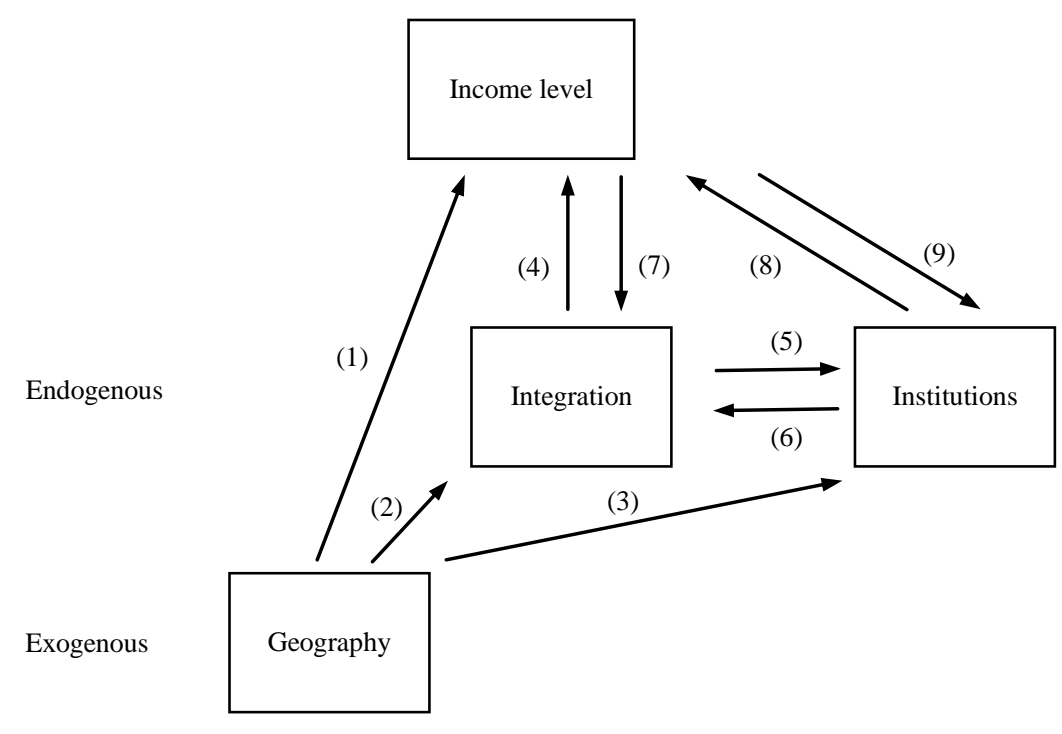

Source: Rodrik et al. (2004).

\section{Literature Review}

There are considerable studies on investigating the causes of the regional inequality in China. Among these studies, three strands of thoughts stand out. The first strand works on the decomposition of the overall inequality, the inter-provincial inequality here, into the within and between components ("decomposition analysis" hereafter). Regional inequality is a multiscale phenomenon (Tsui, 1993; Wei, 2002). Two major geographical scales are generally adopted in the literature, namely the rural-urban and the inland-coastal divisions. Therefore, the overall inequality can be decomposed into contributions from the within-rural, within-urban and rural-urban components, or alternatively, from the 
within-inland, within-coastal and inland-coastal components. It is found that the rural-urban component is the main source of the overall inequality but its contribution does not change very much over time. In contrast, the inland-coastal inequality has increased prominently since the 1990s and become the most important contributor to the overall inequality (Kanbur and Zhang, 1999; Lee, 2000; Bhalla et al., 2003).

A second strand of studies examines China's regional inequality in the context of convergence by estimating cross-province growth regressions ("convergence analysis" hereafter). Numerous studies show that if some variables such as geographical location, physical and human capital, infrastructure, institutions and policies are controlled for in the regressions, then the convergence can be observed (Jian et al., 1996; Chen and Fleisher, 1996; Démurger, 2001). Therefore these conditioning factors, which represent the heterogeneous steady states, are considered to cause income gap across provinces. On the other hand, standard neoclassical growth theory suggests that convergence only occurs among closely integrated economies with factor mobility. The law of diminishing returns and technology transfer would gradually close the income gap across economies. However, such preconditions are hardly valid in China. Thus, the factors that violate of these assumptions are argued to be responsible for the persistence of regional inequality. For instance, institutional barriers such as the household registration system (hukou) have led to the distortions in the labor market and therefore hampered the convergence (Cai et al., 2002; Lin et al., 2004). While labor becomes more mobile in recent years, the poor regions may suffer a drain of the most able members of their labor force and a deterioration of overall human capital quality (Lu, 2008). Large capital inflow did not depress the return of capital and the real wage in the coastal areas, which continuously benefit from the international technological diffusion (Fleisher and Chen, 1997; Bao et al., 2002). Due to local protectionism, geographical distance and structure of exports and FDI, there are only limited spillover effects from growth centers in the coastal areas to inland regions (Brun et al., 2002; Poncet, 2003; Fu, 2004).

Finally, a third stand of studies explores the relative contributions of factor inputs and efficiency to the income inequality across regions ("accounting analysis" hereafter). Using growth accounting method, Liu and Li (2006) show that the inequality in the use of technology, physical and human capital stock is responsible for the inequality in regional income growth. In particular, technology is more important in coastal provinces than in inland provinces. Human capital is endogenous in coastal provinces while it is exogenous in inland provinces. Hao (2007) conducts a development accounting analysis and finds that differences in TFP and in physical capital intensity are both important sources of cross-province income differences, each accounting for roughly half of the income variation. Differences in human capital accumulation, however, explain only a small amount of income differences across provinces. $\mathrm{Lu}$ (2008) relaxes the assumption that the production function and its coefficients are the same across provinces. The variances in capital per employee and factor elasticity are found to be the two main sources of income disparity across provinces.

None of the three strands of studies offer the fundamental causes of regional inequality in a comprehensive way. Both the "decomposition analysis" and the "accounting analysis" provide at best proximate causes of regional inequality. But the questions still remain: why the inland-coastal inequality increased so rapidly in recent years? Why did the coastal provinces accumulate more capital and acquire higher efficiency than the inland provinces? The "convergence analysis" provides 
incomplete albeit plausible explanations. It is well-known that growth regressions show association and not necessarily causation and, if causation, the proximate and not necessarily the underlying causes. In brief, while there is a substantial literature on the issue, systematic studies to explore the "deeper" causes of China's regional inequality has been limited.

This paper aims at contributing to the literature through investigating the fundamental reasons underlying the widening inland-coastal inequality in China during the reform period 1978-2004. The paper differs from previous studies as follows. First, we focus only on inland-coastal inequality because its rapid increase is the most prominent phenomenon in China during the post-reform period. No attempt is made to investigate the causes of inequality in the rural-urban division in this paper.

Second, we investigate the deep-rooted determinants of regional inequality in a systematical framework. Development theories suggest that geography, integration and institutions are the fundamental determinants of income (Rodrik et al. 2004). China's experience with regional development can be an interesting case to test such theories in its variant of income inequality. China is a large country with varying regional characteristics. Geography may have direct and indirect effects on regional income (Song et al., 2000; Démurger et al., 2002). China is also a country in which the government is highly involved in economic activities. Before 1978, it was a planned economy and the state exerted an overwhelming influence on economic development. Since the launch of reforms in 1978, the central government has still played a crucial role in regional development. Meanwhile, with the implementation of the reform policies, specific localities, domestic and global investors have emerged as important agents. Their responses to the central government's policies further influence the actual effects of the policies. The central government, the localities and the investors, act simultaneously and interactively in shaping regional inequality.

A few recent studies appear to be in line with the above framework in identifying the underlying causes of regional inequality. Kanbur and Zhang (2004), for example, show evidence that three policy variables, namely heavy-industry bias strategy, fiscal decentralization and trade liberalization, have systematically affected regional inequality. Inequalities at different scales (i.e., inter-provincial, inland-coastal and rural-urban) seem to be influenced by these policies in different time phases and to different extent. Bao et al. (2002) quantitatively analyze the role of geography on the inland-coastal gap, with an effort of disentangling the effects of geographic factors from those of economic policies. Démurger et al. (2002) explicitly investigate the relative contributions of geography and policy in China's regional development. However, their measure of "preferential policy" is a constructed index which may only reflect the opening-up policy. The effects of decentralization and marketization on regional development have not been sufficiently incorporated. In addition, empirical evidence based on cross-section data with a very limited number of observations may be subject to small sample bias and therefore not much convincing.

Finally, we use both time series and panel data to estimate the effects of the three policy variables (globalization, decentralization and marketization) on inequality. In the time-series analysis, the inland-coastal component of total Theil index is used as the dependent variable, while in the panel data analysis, a gap model is applied (Kanbur and Zhang, 2004; Fu, 2004). 


\section{Evolution of regional inequality in China}

We employ the widely used per capita GDP (PCGDP) as the main indicator of regional income. In most of the early studies, the Soviet-type statistics are used, such as gross value of industrial and agricultural output (GVIAO, e.g., Tsui, 1993; Rozelle, 1994), net material product (NMP, e.g., Lyons, 1991), or national income (NI, e.g., Wei et Ma, 1996). It is due mainly to the lack of data for GDP before $1994^{1}$. However, these measures are different from GDP in that the service sector is excluded. Many recent studies take household consumption as the measure of regional income, particularly in the studies on the rural-urban inequality (Kanbur and Zhang, 1999). Consumption is a good proxy for living standard and permanent income from a welfare perspective. But it may incorporate the redistribution of income among regions by the central and local governments. In contrast, GDP represents the final products made by enterprises as well as self-employed individuals residing in a region, and is therefore a better measure of regional economic development

In addition, per worker GDP (PWGDP) is taken as an alternative proxy for regional income. PWGDP is also extensively used in the literature, especially in the studies on growth accounting and growth regressions. The relationship of PCGDP and PWGDP is displayed as follows:

Eq.(1) $\mathrm{Y} / \mathrm{P}=\mathrm{Y} / \mathrm{W} \mathrm{W} / \mathrm{A} \mathrm{A} / \mathrm{P}$

Namely, PCGDP, shown by Y/P, is the product of PWGDP (Y/W), the employment rate (W/A) and labor force participation ratio (A/P). This implies that PWGDP and PCGDP are closely related but distinct. Regional inequality derived by PCGDP should be distinguishable from that by PWGDP, if the employment rate and labor participation ratio differ across regions. Under the assumption of neoclassical convergence, the regional inequality in PWGDP will eliminate gradually through the law of diminishing returns and technology transfer. Regional differences in the employment rate and the long-term labor participation ratio, however, indicate the disparities in labor market functioning and demographic transition. These disparities across regions are particularly evident in China during the post-reform period, leading to discrepancies between inequality by PCGDP and that by PWGDP.

Our data source is the newly released Comprehensive Statistical Data and Materials on 55 Years of New China (2005) published by the National Bureau of Statistics (NBS). It provides us consistent data on provincial GDP during 1952-2004 to make a comprehensive assessment on China's regional development. We exclude Hainan and Tibet from our analysis due to data unavailability before 1978 . Chongqing has no separate data until it has become a fourth municipality in 1997 . We therefore incorporate the data for Chongqing in those for Sichuan to maintain sample consistency. In short, our sample includes 28 provinces in the pre-reform period (1952-1977) and 30 provinces in the post-reform period (1978-2004). Nevertheless the sample concerning PWGDP involves 22 provinces in the pre-reform period because we further exclude six provinces (Beijing, Hebei, Inner Mongolia, Zhejiang, Anhui and Sichuan) with incomplete data for employment in 1952-1977. All current GDP values are converted into real terms in 1995 constant prices by using the provincial implicit GDP deflators.

Regarding the index of inequality, there are a number of indexes available (Coulter, 1989; Shankar and

\footnotetext{
${ }^{1}$ It is from this year that Chinese official statistics changed from the Material Product Balances System (MPS) to the System of National Accounts (SNA).
} 
Shah, 2003). In this paper, we employ the Theil index, which can be formulated as follows ${ }^{2}$ :

Eq. (2) $\quad \mathrm{I}(\mathrm{y} ; \mathrm{n})=(1 / \mathrm{n}) \sum_{\mathrm{i}} \log \left(\mu / \mathrm{y}_{\mathrm{i}}\right)$

where $\mathrm{y}_{\mathrm{i}}$ is the $i$ th provincial income, $\mu$ is the mean income $\sum_{\mathrm{i}}\left(\mathrm{y}_{\mathrm{i}} / \mathrm{n}\right)$, and $\mathrm{n}$ is the number of provinces. The higher the Theil index, the greater the inequality. This index is additively decomposable, which makes it possible to look deeply into the composition of inequality:

Eq.(3) $\quad \mathrm{I}(\mathrm{y} ; \mathrm{n})=\sum_{\mathrm{g}}\left(\mathrm{n}_{\mathrm{g}} / \mathrm{n}\right) \mathrm{I}\left(\mathrm{y}^{\mathrm{g}} ; \mathrm{n}_{\mathrm{g}}\right)+(1 / \mathrm{n}) \sum_{\mathrm{g}} \mathrm{n}_{\mathrm{g}} \log \left(\mu / \mu_{\mathrm{g}}\right)$

where $\mathrm{n}_{\mathrm{g}}$ is the number of provinces in the $g$ th sub-sample, and $\mathrm{I}\left(\mathrm{y}^{\mathrm{g}} ; \mathrm{n}_{\mathrm{g}}\right)$ is Theil index in the $g$ th sub-sample. The total inequality I $(\mathrm{y} ; \mathrm{n})$ is expressed as the sum of a "within-group" inequality term and a "between-group" term. The within-group inequality is a weighted sum of the sub-group inequality values (Shorrocks, 1980). It should be noted that empirical studies on regional inequality have long been troubled by whether the inequality measure should be weighted by provincial population (Lyons, 1991; Chen and Fleisher, 1996). Based on the unweighted measures, the Theil indexes we compute in this paper are similar to those weighted by provincial population in Bhalla et al. (2003) and Kanbur and Zhang (2004).

Fig.2 plots the calculated Theil indexes based on PCGDP and PWGDP over 1952-2004. The main message from this figure is that the evolution of inequality appears to well match China's development phases dominated by different policy episodes. The temporal patterns of inter-provincial inequality fluctuated strongly during the pre-reform period, indicating few improvements in reducing inequality. The inter-provincial inequality in terms of PCGDP rose sharply during the Great Leap Forward (1957-1960) and the Cultural Revolution (1966-1976). It declined steadily during the agricultural reform (1978-1984) and the Lange-type market socialism period (1985-1991). Since then it started to increase dramatically as China entered the period of "socialist market economy with Chinese characteristics", when more policies have been intensively implemented to accelerate the economic growth. Not until recent years has it decreased slightly as the consequences of the "western development strategy" adopted in 1998 and the "north-east revival strategy" in 2002. By comparison, the inter-provincial inequality in terms of PWGDP presents a similar picture in spite of a few differences in the turning point ${ }^{3}$. The Theil index by PWGDP declined slightly in the early years of economic reforms and then rose rapidly in 1985-2000. The comparison of the two Theil indexes may partly explain the different claims in the literature on the year in which inequality starts to increase significantly in the post-reform period. As our finding suggests, the measure of regional inequality is very sensitive to different proxies for regional income.

\footnotetext{
2 The Theil index used in this paper is one of the generalized entropy of inequality measures with a parameter $\mathrm{c}=0$. In the family of entropy measures, this index is the most satisfactory in the sense that the within-group inequalities and the between-group inequality are independent of each other (Shorrocks, 1980, pp. 625).

${ }^{3}$ Note that in the pre-reform period, the inequality indexes in terms of PCGDP and PWGDP can not be directly compared due to different sample sizes. In particular, the sample for PWGDP does not include Beijing, one of the three municipalities whose inclusion or omission may affect the analysis result (Démurger et al., 2002).
} 


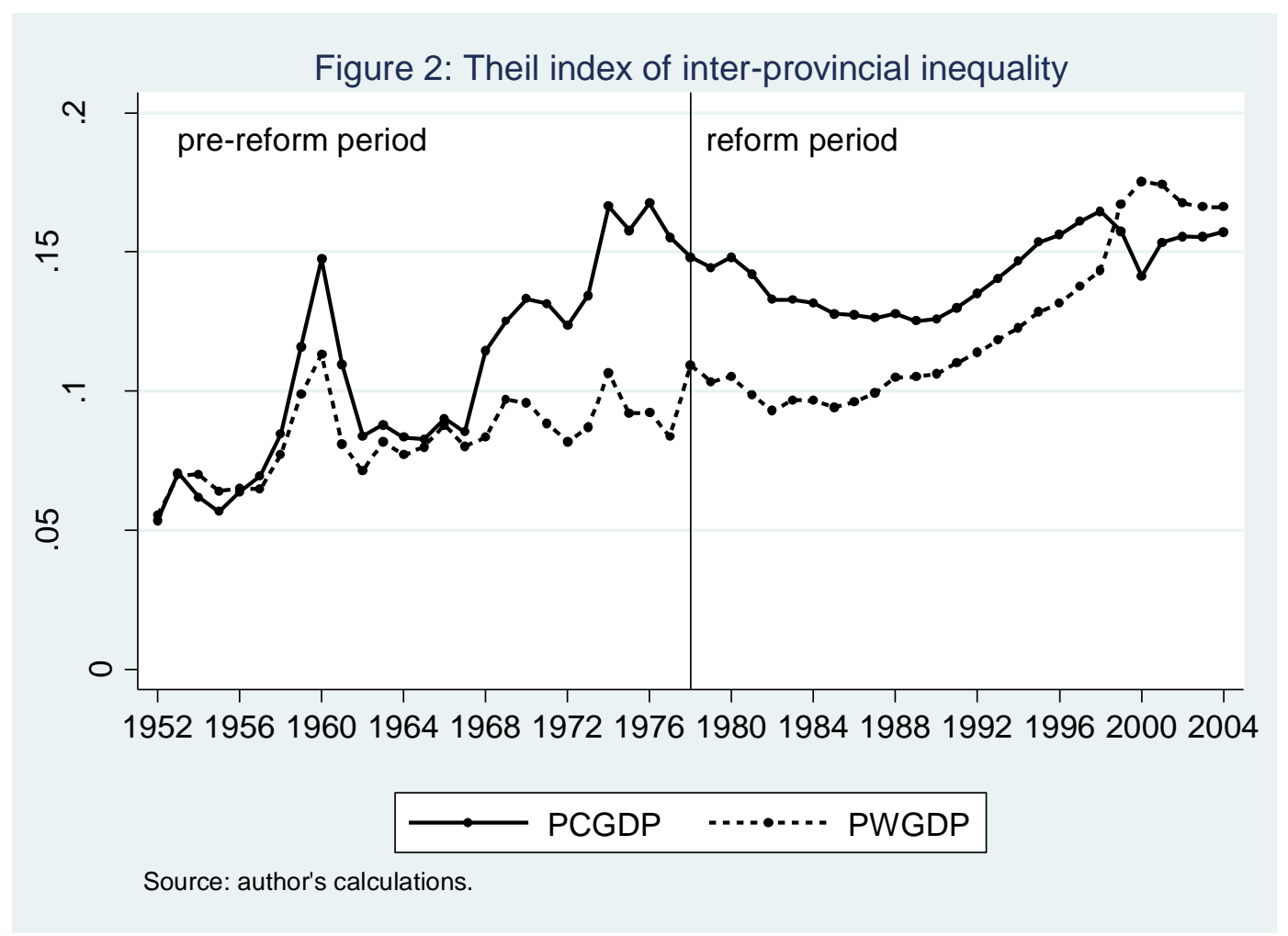

Next, we analyze China's regional inequality by decomposing it with respect to specific regions. The mainland China is comprised of the eastern, central and western regions according to geographic locations or, alternatively, the coastal and inland regions (see Appendix). ${ }^{4}$ Following Eq.(3), we decompose the inter-provincial inequality into three components: within-inland inequality, within-coastal inequality and inland-coastal inequality. The respective patterns of these three components in terms of PCGDP and PWGDP are displayed in Fig.3. It is clear that the inter-regional inequality, or the inland-coastal inequality here, has been rising throughout the period and experienced a sharp increase in the 1990s. As a result, the inland-coastal inequality has become the largest contributor to China's inter-provincial inequality since the 1990s. For example, in 2000 it explains $60.89 \%$ and $51.50 \%$ of inter-provincial inequality in terms of PCGDP and PWGDP respectively.

Furthermore, unlike the two within-group inequality components, the inland-coastal inequality shows a similar pattern with inter-provincial inequality in terms of trend and turning points. This indicates that the evolution of the inland-coastal inequality also coincide with changes of Chinese government policies. This finding does not alter when the three municipalities, i.e., Beijing, Tianjin and Shanghai, are excluded, as shown in Fig.4. However, we find that the exclusion of these municipalities makes the inland-coastal gap almost disappear in the pre-reform period, if taking a careful comparison between Fig. 3 and Fig. 4 on the inland-coastal inequality in terms of PCGDP ${ }^{5}$. This implies that the inland-coastal inequality in the pre-reform period is rather attributed to the disparity between inland provinces and three municipalities than that between inland and other coastal provinces. In contrast, it

\footnotetext{
${ }^{4}$ The eastern region is also referred as the coastal region and the central and western regions together as the "inland" or "interior" region.

${ }^{5}$ We do not report the results of inequality decomposition without three municipalities in terms of PWGDP, mainly because our PWGDP data already exclude Beijing. We can see from Fig. 3 that even if only Beijing is omitted, the inland-coastal inequality during the pre-reform period becomes quite flat and can even be neglected.
} 
is since the economic reforms that the inland-coastal inequality started to increase in its real sense $\mathrm{e}^{6}$.

Figure 3: Decomposition of inter-provincial inequality
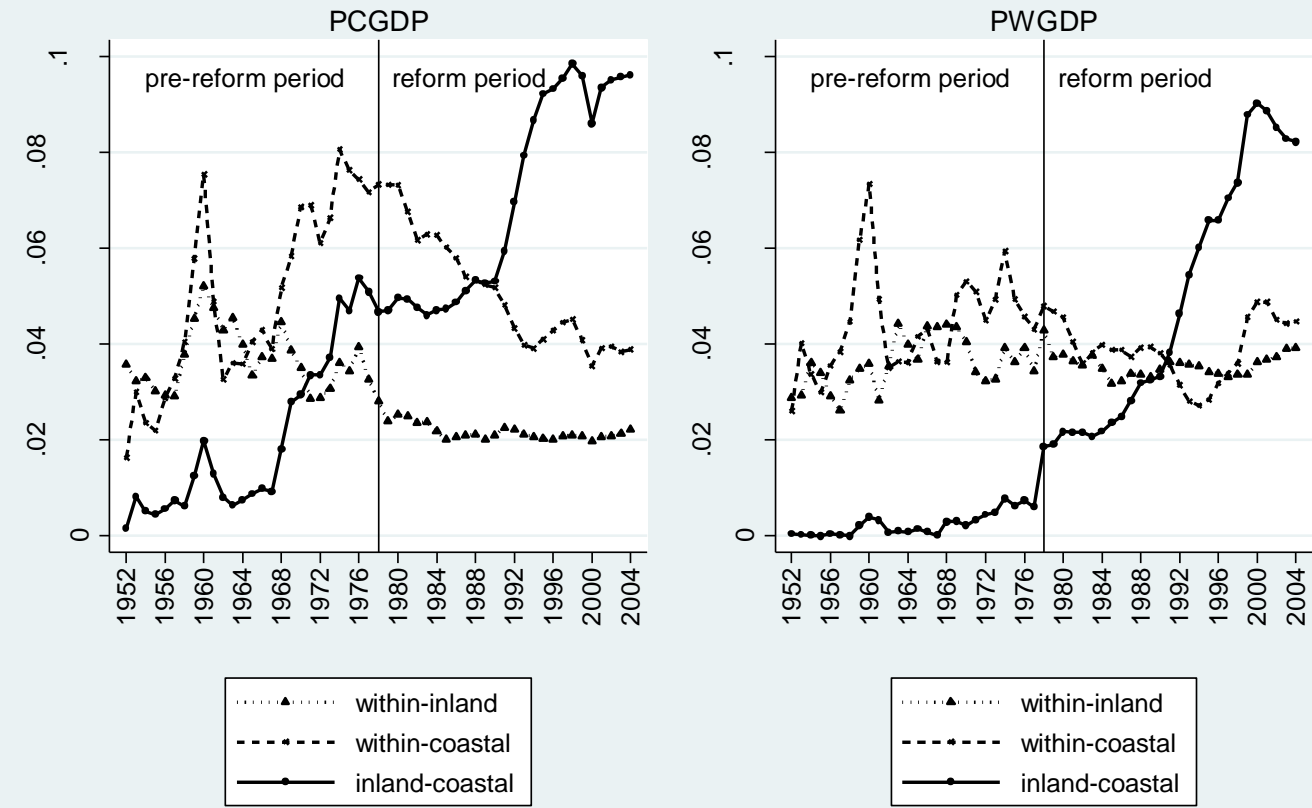

Source: author's calculations.

Figure 4: Sample without three municipalities
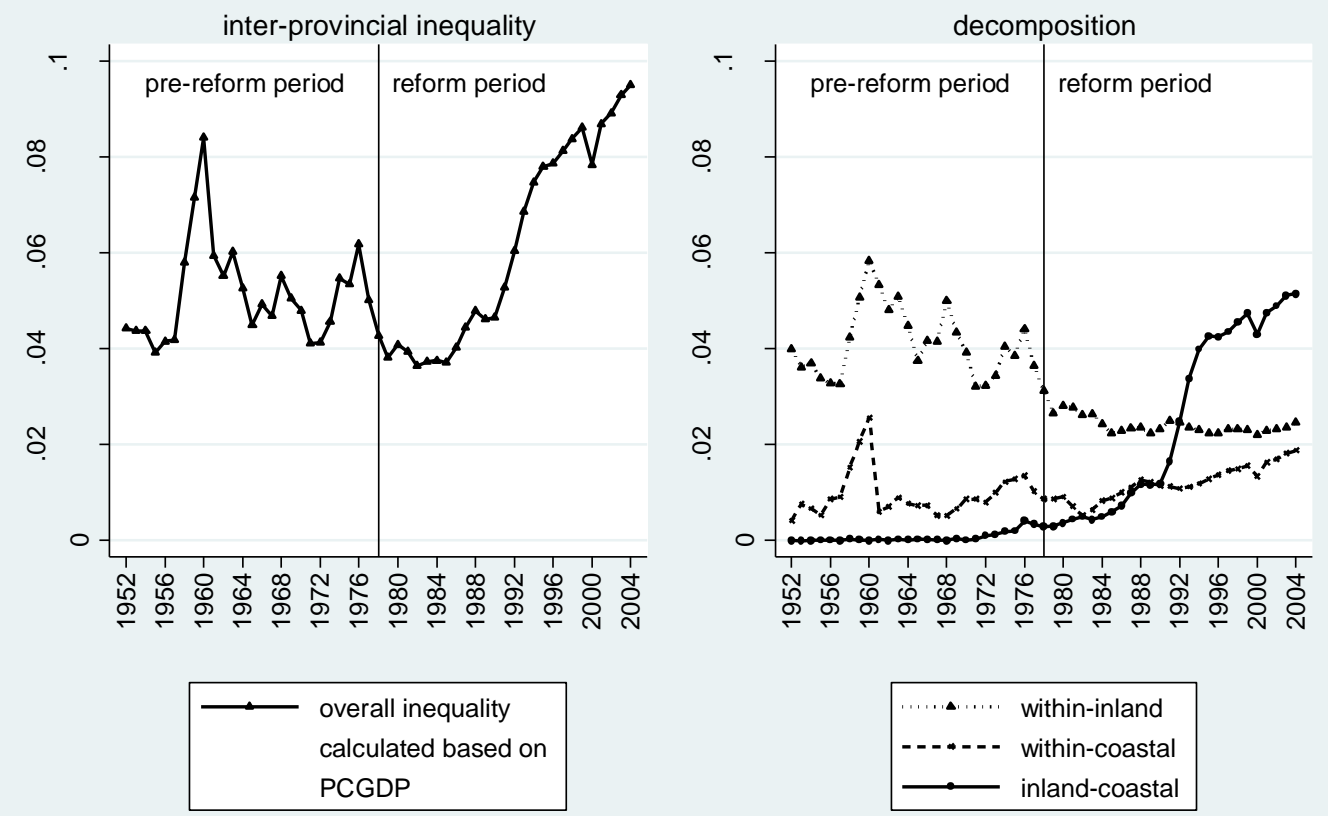

Source: author's calculations.

\footnotetext{
${ }^{6}$ Remember that the official classification of coastal (eastern) and inland (comprising central and west) regionalization appeared for the first time in China's Seventh Five-Year Plan (1986-1990).
} 
In brief, during the pre-reform era, both inter-provincial inequality and inland-coastal inequality persisted, but the latter is rather seen as a gap between the three municipalities and other provinces. In the post-reform period, inter-provincial inequality displays a U-shaped evolution in general, whereas inland-coastal inequality rises continuously. In particular, a sharp rise occurred in the 1990s in the inland-coastal inequality, which has thereby become the largest contributor to the inter-provincial inequality. The changing patterns of China's regional inequality are closely related to the major political events as well as government policies adopted in different phases.

\section{Government policies and inland-coastal inequality in China}

The central hypothesis in this paper is whether the government policies with regard to globalization, decentralization and marketization have contributed to the widening inland-coastal gap since the reforms. Below we provide a brief discussion of the regional implications of each of these three policies. The theoretical relationships will be tested empirically in Sections 5.

\subsection{Globalization (opening-up)}

In 1978, after nearly 30 years of isolation, China started to rejoin the world economy. Acknowledging the critical importance of trade, foreign capital and advanced technologies to China's modernization, the Chinese government implemented the "open-door" policy to replace the "self-reliance" policy dominating the pre-reform era. The early strategy of opening-up was strongly influenced by the "ladder-step theory". Higher priority was given to the coastal areas because of its proximity to seashore and the connection of oversea Chinese. It is also expected that the development of coastal region can gradually trickle down to inland areas. This strategy of gradual and incremental opening-up may have directly contributed to the enlarging of regional income disparities (Yang, 2002).

The opening policies in the 1980s, guided by the "Coastal Development Strategy", were very favorable to the coastal provinces. In 1980, China established four special economic zones (SEZs) in Guangdong and Fujian. In 1984, another 14 coastal cities in 8 coastal provinces were opened to encourage trade and attract FDI. In early 1985, three "development triangles", namely the Yangtze River delta, the Pearl River delta and the MinNan region in Fujian, were designed to open as Coastal Open Economic Zones. These opened areas acquired considerable autonomy, enjoyed tax treatments, and received preferential resource allocations. Moreover, in these areas, approvals of new investment projects or import/export rights were more easily and rapidly achieved. Hence transaction costs lowered (Wen, 2007). Preferential policies were subsequently extended to more Open Coastal Belt, to the entire Hainan Island, to the Shanghai Pudong New Area, and by the end of the 1980s to all coastal areas. As a consequence, the coastal provinces attracted disproportionately high shares of FDI and trade. Table 1 clearly shows that most of trade and FDI in China were concentrated in the coastal provinces in 1979-1990. In particular, Guangdong province alone accounted for $35.13 \%$ of the cumulative total trade and $37.47 \%$ of the total FDI, while the combined share of inland provinces was only $14.05 \%$ for trade and $18.01 \%$ for FDI.

The uneven patterns of economic opening have even been reinforced in the 1990s. After Deng Xiaoping's southern-tour in 1992 calling for more opening and economic acceleration, radical opening 
policies were initiated to encourage more FDI and trade. Meanwhile, the opening policies were extended to inland areas. However, during 1991-2004, an overwhelming portion of the trade volume $(91.17 \%)$ was taken into account by coastal provinces and far more FDI $(84.71 \%)$ was attracted there, as Table 1 shows.

One explanation for this is that the coastal region is never neglected by the government policies. But the sequence and time lags in economic opening provide another explanation (Hao, 2008). In the early opened coastal provinces, deregulation policies of the external sector facilitated their inherent local comparative advantages, such as convenient geographical location, better economic foundations, skilled labor, and socio-cultural business traditions. Earlier exposure to international competition compels them to pay more attention to operational efficiency of enterprises. Dramatic increase of FDI in the coastal region contributed to economic growth in general and to export industry in particular. Labor-intensive manufacturing exporting firms have developed and rapidly expanded in the coastal areas, further attracting factors of production from backward inland provinces. Hence, opening policy, geography, institutions and growth are interacted in complex way involving a gradual but rapid process of cumulative causation. A significant industrial agglomeration occurred, making the coastal region being the growth center of the country. As a result, the income levels of inland and coastal regions diverged at an even faster pace.

In brief, the opening policy at the early stages of reform is biased against inland regions. Although all regions are gradually given more or less uniform preferential policies, the coastal region benefits more from globalization than the inland regions due to the timing of opening-up and the consequences of cumulative causation. The extremely uneven geographical distribution of exports and FDI may have directly translated into widening inland-coastal inequality.

Table 1: Regional distribution of international trade volume and FDI in China

\begin{tabular}{|c|c|c|c|c|}
\hline & \multicolumn{2}{|c|}{ International trade } & \multicolumn{2}{|c|}{ FDI } \\
\hline & $\%$ of total $1979-1990$ & $\%$ of total $1991-2004$ & $\%$ of total $1985-1990$ & $\%$ of total $1991-2004$ \\
\hline Coastal & 85.95 & 91.17 & 81.99 & 84.71 \\
\hline Beijing & 2.76 & 2.43 & 9.70 & 3.71 \\
\hline Tianjin & 3.64 & 3.50 & 2.31 & 4.37 \\
\hline Hebei & 2.82 & 1.31 & 0.75 & 2.13 \\
\hline Liaoning & 9.14 & 3.93 & 4.22 & 5.44 \\
\hline Shanghai & 11.31 & 11.92 & 9.23 & 8.32 \\
\hline Jiangsu & 5.01 & 11.23 & 3.07 & 14.55 \\
\hline Zhejiang & 2.88 & 6.41 & 1.33 & 4.69 \\
\hline Fujian & 3.78 & 5.01 & 6.98 & 8.26 \\
\hline Shandong & 7.45 & 5.63 & 2.78 & 7.44 \\
\hline Guangdong & 35.13 & 38.68 & 37.47 & 23.17 \\
\hline Guangxi & 1.21 & 0.63 & 1.41 & 1.23 \\
\hline Hainan & 0.82 & 0.50 & 2.73 & 1.40 \\
\hline Inland & 14.05 & 8.83 & 18.01 & 15.29 \\
\hline Shanxi & 0.58 & 0.43 & 0.14 & 0.37 \\
\hline Inner Mongolia & 0.51 & 0.46 & 0.14 & 0.34 \\
\hline
\end{tabular}




\begin{tabular}{|c|c|c|c|c|}
\hline Jilin & 1.21 & 0.74 & 1.55 & 1.30 \\
\hline Heilongjiang & 1.61 & 0.90 & 3.44 & 1.65 \\
\hline Anhui & 0.92 & 0.75 & 0.23 & 0.77 \\
\hline Jiangxi & 0.83 & 0.39 & 0.21 & 1.28 \\
\hline Henan & 1.21 & 0.63 & 1.61 & 1.98 \\
\hline Hubei & 1.74 & 0.83 & 5.03 & 2.60 \\
\hline Hunan & 1.34 & 0.61 & 0.36 & 1.61 \\
\hline Sichuan & 1.45 & 1.10 & 1.04 & 1.56 \\
\hline Guizhou & 0.23 & 0.17 & 0.62 & 0.26 \\
\hline Yunnan & 0.83 & 0.49 & 0.16 & 0.29 \\
\hline Tibet & 0.04 & 0.03 & 0.02 & 0.01 \\
\hline Shaanxi & 0.54 & 0.49 & 2.57 & 0.72 \\
\hline Gansu & 0.25 & 0.17 & 0.13 & 0.12 \\
\hline Qinghai & 0.08 & 0.05 & 0.04 & 0.23 \\
\hline Ningxia & 0.14 & 0.09 & 0.41 & 0.12 \\
\hline Xinjiang & 0.56 & 0.51 & 0.30 & 0.08 \\
\hline
\end{tabular}

Source: Author's calculations based on NBS (2005).

\subsection{Fiscal decentralization}

China's fiscal system has significantly contributed to uneven regional development (Wei, 1996). The fiscal system in the pre-reform era was featured by centralized revenue collection and inter-regional budget transfers, giving few incentives to the provinces for developing their economies. The spending of the central government was mainly for sectoral and strategic reasons. Many inland provinces, including Gansu, Henan, Hubei, Hunan and Sichuan, received a massive inflow of state investments, but the economic return were poor (Naughton, 1988). Meanwhile, the industrial bases of the coastal region were not effectively utilized because they generally lacked sufficient funds to improve urban services and update industrial facilities. However, the short-lived fiscal decentralization, which took place in the late 1950s and the early 1970s, laid the foundation for the development of the TVEs in the coastal provinces (Wei, 2002). The three municipalities received special treatment from the central government, such as cheap raw and energy materials, interest-free loans, and planned commercial networks. They therefore maintained the leading roles in economic development over the rest of the country.

Such a centralized fiscal system has been gradually changed since the economic reforms. Fiscal decentralization has become one of the major characteristics of fiscal reforms throughout the transition period. The 1980s were marked by the gradual establishment of the "contract-responsibility system", which gave the provinces considerable budget autonomy to arrange their revenues according to their own wishes. Both budgetary and extra-budgetary funds have increased dramatically and the center's control over local expenditures has been greatly reduced. Revenue has been more closely tied to expenditure, which provided local governments more financial power and incentives to actively engage in local economic development. Such fiscal decentralization has contributed to the widening regional inequality. First, inter-regional fiscal transfer has been significantly reduced and the center has now become incapable of assisting the poor regions. Second, the provinces differ considerably in revenue 
sharing with the central government and in timing of adopting the contract-responsibility system. Third, the proliferation of extra-budgetary funds has further differentiated the provinces in local spending.

Since the early 1990s, a new "tax-sharing system" was experimented and fully implemented in 1994. This reform attempts to reassert the central power of macro-control by withdrawing revenue that had been substantially decentralized to the accounts of local governments in the early reform (Zhao and Zhang, 1999). By dividing taxes into central, local and shared ones collected by central or local fiscal agencies, the tax-sharing system clearly specifies fiscal responsibilities of central and provincial governments and replaces the traditional bargaining in determining central-provincial revenue-sharing rates. However, the impact of this new fiscal system is still regionally uneven. First, the tax-sharing system did not change the resource distribution which was still determined largely by the current assets the provinces occupied. Local governments are stimulated to enlarge as much as possible their assets and resource possession, so as to enlarge their power in the allocation and distribution of central resources. Backward regions tended to use their administrative powers, which were dramatically heightened by the fiscal decentralization, to protect their own interests through blockading interregional trade and hoarding local resources and products. This has led to regionalism and market segmentation that prevent spillover effects.

Second, the inland regions usually accommodated more centrally affiliated enterprises than the coastal region. The revenue generated by these enterprises was required to be submitted to the center. For example, Yunnan and Guizhou that specialize in cigarettes and liquor had to remit huge taxed generated from these products to the center. Thus, the inland provinces gain disproportionally less than the coastal provinces from the decentralization reforms.

Third, fiscal decentralization caused sharply uneven fiscal burdens in regions with different economic structures (Zhang, 2006). The coastal areas, which are endowed with a broader non-agricultural tax base, do not need to rely heavily on existing or new enterprises to finance public goods provision. This helps create a healthy investment environment for economic development ("a helping hand"). In contrast, the inland regions with agriculture as the major economic activity have little resources left for public investment after paying the bureaucracy expenses. They have to extract more levies on their industrial enterprises because of lower tax collection cost on firms relative to agricultural taxes on households. Therefore the implicit industrial tax rate tends to be higher in these regions, which would discourage potential investment and drive away existing enterprises ("a grabbing hand"). As a result, a vicious cycle of insufficient revenue, heavier fiscal burden and worse investment environment occurred, hampering the growth of non-agricultural sector in the inland regions.

Finally, political recentralization since the early 1990s reinforced the effect of the fiscal decentralization on regional inequality (Zhang, 2007). One of the important changes in political recentralization was to introduce a performance-based cadre promotion system, which gave rise to a "political championship" governing local officials. Local governments were motivated to favor capital construction and compete for investment-led growth. Despite a quite rapid economic growth in general, regional inequality may have been exacerbated due to the fact that economically prosperous coastal regions can attract more capital from foreign and domestic sources. 
In brief, fiscal reforms since the late 1970s offered considerable fiscal autonomy and incentives to local governments to develop their economies. However, fiscal decentralization would systematically enlarge regional inequality. Each time the central government decentralized economic power to give local levels more authority, the coastal areas have invariably performed more efficiently than the inland regions by virtue of their favorable local conditions and comparative advantages.

\subsection{Marketization}

Marketization is also an important source of regional inequality. It is generally accepted that market reforms in China have contributed to the rapid economic growth, through improving economic incentives, optimizing resource allocation and removing impediments to private sector development (Chen and Feng, 2000; Laurenceson and Chai, 2000). However, as a result of state policy and local conditions, regions differ greatly in ownership transformation and market institutions.

Ownership transformation, the development of non-state sectors in particular, is central to China's marketization, which disproportionately benefited the coastal provinces for two reasons. First, since the reforms, the non-state sectors, especially town and village enterprises (TVEs) in the 1980s and since 1992, foreign-invested enterprises (FIEs) and private enterprises, have dominated the coastal region? ${ }^{7}$ As Table 2 shows, coastal provinces, especially Jiangsu, Zhejiang, Guangdong, Fujian and Shandong, have much higher proportion of output and labor absorption by non-state enterprises. The non-state sectors are less regulated and more flexible in responding to the market and state policy. They performed more efficiently and therefore the coastal provinces grew more rapidly. Their phenomenal growth has led to the rise of the inland-coastal gap in China.

Second, while the inland provinces were dominated by resource-based heavy industry state-owned enterprises (SOEs), most of the SOEs in the coastal provinces were light industry. A dual-track price system was introduced in 1984 for SOEs, allowing them to go beyond the state planning system and trade their products in the market at prices varying around the planned prices by 20 percent. The prices of small consumption commodities were determined by the market, and the prices of some light industrial products were adjusted according to market demand (Wen, 2007). The dual-track price liberalization encouraged investment and led to an above-average rate of TFP growth in light industry, contributing to faster growth in the coastal areas (Raiser, 1998).

In addition to faster ownership transformation and more diversified ownership structure, a more sophisticated market system has been established in the coastal region. As Table 3 shows, the coastal region has a better integration of developed product markets, factor markets, intermediary markets, and a more efficient legal system. Meanwhile, local governments in the coastal region tend to intervene less in business decisions. In contrast, inland regions lagged behind in developing these key market institutions, which in turn increased transaction costs of enterprises and affects regional attractiveness to draw in investments. They therefore experienced slower economic growth, further enlarging the gap

\footnotetext{
7 The classification of ownership structure in China is extremely complicated, and traditionally includes three ownership categories: "state-owned enterprises" (SOEs), "collective-owned enterprises" (COEs)", and "others". The non-state sector refers to enterprises other than SOEs. COEs include urban COEs and rural COEs (township and villages enterprises, TVEs). The "others" category includes foreign-invested enterprises (FIEs), limited liability corporations (LLCs), shareholding corporations (SHCs), shareholding enterprises (SHEs), jointly owned enterprises (JOEs), and private/individual enterprises (PEs). See Wei (2004) for details.
} 
from their coastal counterpart.

In brief, marketization reforms defined a climate that promoted the remarkable development of the non-state sectors and market institutions in the coastal areas. The inland regions have had difficulty in reforming the SOEs and developing non-state sectors. Regions exhibits varied trajectories of ownership transformation and market fostering, which have enlarged the inland-coastal income inequality.

Table 2: Development of non-state sector by regions

\begin{tabular}{|c|c|c|c|c|c|c|c|c|}
\hline & \multicolumn{4}{|c|}{ Share of non-SOEs in total industrial production } & \multicolumn{4}{|c|}{ Share of non-SOEs in total staff and worker } \\
\hline & 1978 & 1985 & 1992 & 2000 & 1978 & 1985 & 1992 & 2000 \\
\hline Coastal & 23.88 & 35.73 & 50.78 & 79.42 & 23.75 & 27.52 & 27.64 & 34.42 \\
\hline Beijing & 9.99 & 18.14 & 33.29 & 71.57 & 17.38 & 19.42 & 22.05 & 34.82 \\
\hline Tianjin & 19.26 & 27.90 & 50.68 & 81.87 & 22.59 & 25.76 & 27.64 & 37.14 \\
\hline Hebei & 23.60 & 46.29 & 55.20 & 67.62 & 16.91 & 23.58 & 23.34 & 23.65 \\
\hline Liaoning & 15.28 & 25.75 & 29.32 & 68.79 & 24.31 & 34.71 & 34.00 & 30.32 \\
\hline Shanghai & 8.30 & 22.01 & 42.81 & 82.56 & 20.46 & 22.17 & 22.42 & 41.05 \\
\hline Jiangsu & 38.54 & 58.88 & 71.77 & 87.30 & 37.00 & 40.08 & 37.76 & 38.89 \\
\hline Zhejiang & 38.66 & 62.83 & 73.59 & 91.85 & 41.47 & 43.57 & 39.36 & 47.76 \\
\hline Fujian & 25.80 & 41.25 & 65.68 & 91.56 & 27.80 & 30.18 & 34.46 & 47.55 \\
\hline Shandong & 32.37 & 41.85 & 58.23 & 80.22 & 24.77 & 29.22 & 27.91 & 31.39 \\
\hline Guangdong & 36.18 & 44.19 & 65.44 & 74.95 & 28.47 & 31.99 & 34.77 & 44.14 \\
\hline Guangxi & 21.15 & 22.22 & 34.37 & 78.16 & 16.03 & 19.75 & 17.07 & 20.49 \\
\hline Hainan & 17.43 & 17.47 & 28.93 & 76.57 & 7.79 & 9.84 & 10.92 & 15.86 \\
\hline Inland & 18.73 & 24.93 & 32.60 & 60.49 & 16.03 & 21.54 & 21.02 & 22.03 \\
\hline Shanxi & 21.94 & 31.50 & 47.93 & 67.88 & 15.27 & 22.70 & 22.59 & 25.27 \\
\hline I. Mongolia & 20.86 & 19.53 & 24.59 & 79.57 & 19.51 & 24.66 & 23.07 & 25.24 \\
\hline Jilin & 21.09 & 25.46 & 30.23 & 57.71 & 23.05 & 32.28 & 29.96 & 25.12 \\
\hline Heilongjiang & 16.88 & 20.35 & 19.77 & 41.51 & 20.29 & 30.63 & 27.24 & 26.59 \\
\hline Anhui & 20.11 & 33.52 & 47.99 & 69.02 & 26.10 & 31.91 & 31.35 & 34.50 \\
\hline Jiangxi & 21.83 & 29.48 & 40.73 & 61.27 & 17.35 & 23.48 & 21.16 & 20.51 \\
\hline Henan & 25.96 & 34.24 & 51.32 & 71.44 & 17.62 & 23.44 & 23.46 & 36.63 \\
\hline Hubei & 22.67 & 31.27 & 37.36 & 64.73 & 18.76 & 25.70 & 23.97 & 23.26 \\
\hline Hunan & 25.01 & 30.56 & 40.97 & 59.48 & 22.46 & 25.76 & 22.74 & 18.24 \\
\hline Sichuan & 15.94 & 28.47 & 43.32 & 77.62 & 15.98 & 26.03 & 31.16 & 28.41 \\
\hline Guizhou & 18.81 & 20.61 & 24.16 & 62.64 & 19.59 & 19.88 & 17.89 & 21.30 \\
\hline Yunnan & 15.28 & 19.92 & 23.84 & 57.25 & 11.75 & 15.43 & 15.50 & 19.30 \\
\hline Tibet & 23.41 & 34.34 & 36.61 & 48.11 & 6.29 & 8.51 & 7.09 & 7.82 \\
\hline Shaanxi & 15.78 & 24.15 & 33.95 & 48.14 & 13.62 & 19.58 & 17.47 & 19.23 \\
\hline Gansu & 6.27 & 11.76 & 24.32 & 57.26 & 9.47 & 13.12 & 18.77 & 17.84 \\
\hline Qinghai & 17.32 & 18.85 & 16.68 & 25.26 & 10.97 & 15.67 & 15.89 & 13.01 \\
\hline Ningxia & 17.18 & 19.09 & 21.36 & 64.36 & 12.22 & 16.20 & 16.34 & 20.06 \\
\hline Xinjiang & 10.88 & 15.67 & 21.65 & 75.60 & 8.29 & 12.73 & 12.70 & 14.21 \\
\hline
\end{tabular}

Note: The non-state sector refers to enterprises other than SOEs, namely COEs and "other". The "other" category includes foreign-invested enterprises (FIEs), limited liability corporations (LLCs), shareholding corporations (SHCs), shareholding enterprises (SHEs), jointly owned enterprises (JOEs), and private enterprise (PEs). 
Table 3: Regional marketization level indexes

\begin{tabular}{lccc}
\hline Index & 1999 & 2000 & Change \\
\hline 1. Development of non-state-owned enterprises & & \\
Coastal & 6.91 & 7.58 & 0.67 \\
Inland & 3.70 & 4.13 & 0.43 \\
2. Reduction of government intervention & & 0.03 \\
Coastal & 7.08 & 7.11 & -0.12 \\
Inland & 5.56 & 5.44 & \\
3. Development of product market & & & 0.22 \\
Coastal & 7.94 & 8.16 & 0.21 \\
Inland & 6.93 & 7.14 & \\
4. Development of factor market & & & 0.25 \\
Coastal & 5.41 & 5.66 & 0.14 \\
Inland & 2.30 & 2.44 & \\
5. Development of intermediaries and efficiency improvement of legal system & 6.43 & 0.30 \\
Coastal & 6.13 & 4.63 & 0.22 \\
Inland & 4.41 & & \\
\hline
\end{tabular}

Note: A description of the approach to the construction of these indexes is provided in the NERI (2001) report. Source: Wen (2007).

\section{Empirical evidence}

\subsection{Results from time-series analysis}

Following Kanbur and Zhang (2004), we first use long run time-series to test the effects of three policy variables on the inland-coastal inequality. To have sufficient numbers of observations, our sample covers both pre-reform and reform period from 1952 to 2004. All data are derived from Comprehensive Statistical Data and Materials on 55 Years of New China (NBS, 2005). A log-linear regression model is specified as follows:

Eq.(4) $\quad \operatorname{ICGAP}_{\mathrm{t}}=\mathrm{c}+\alpha \mathrm{GLOBAL}_{\mathrm{t}-1}+\beta \mathrm{DECEN}_{\mathrm{t}-1}+\gamma \mathrm{MARKET}_{\mathrm{t}-1}+\varepsilon_{\mathrm{t}}$ where ICGAP is inland-coastal inequality, GLOBAL, DECEN and MARKET denote respectively globalization, decentralization and marketization, and $\varepsilon$ is the error term.

The dependent variable, ICGAP, is the calculated inland-coastal Theil indexes based on per capita GDP, as described in Section 3. We do not use the Theil indexes based on per worker GDP because our dataset for the pre-reform period comprise only 22 provinces due to incomplete employment data. As for explanatory variables, GLOBAL is measured by ratio of trade (imports plus exports) to GDP. DECEN is measured by the share of local government expenditure in total government expenditure ${ }^{8}$. As emphasized by Zhang and Zou (1998) and Zhang (1999), the relative size of local revenue

\footnotetext{
${ }^{8}$ Although some other measures are also used as a proxy for GLOBAL or DECEN in the literature, they are not long enough for our time-series analysis.
} 
collection is not a good indicator of China's fiscal decentralization ${ }^{9}$. Although marketization may be a composite of a number of indicators, there are no data on these indicators over such a long time span except for ownership transformation. Given the fact that ownership transformation is the major element of China's marketization, it can be served as an appropriate indicator for MARKET. Ownership transformation can be measured in many ways, including output and employment. We use the share of non-state enterprises in industrial production (NSOEPR) as our major measure of MARKET. Then we check the robustness of the results to the use of another available proxy for MARKET, namely the share of non-state enterprises in total staff and workers (NSOEST).

Our hypothesis is that policies with respect to globalization, decentralization and marketization intensify the inland-coastal inequality. Therefore we expect GLOBAL, DECEN and MARKET have positive coefficients. All variables are in logarithms. One-year lagged values of the explanatory variables are used in the regression to reduce potential endogeneity problems, because it is impossible to find appropriate instruments covering the entire 1952-2004 period under consideration (Kanbur and Zhang, 2004).

Before we discuss the regression results, it is useful to look at the simple bivariate relationships between inland-coastal inequality and each of the policy variables. Table 4 presents the correlations matrix. First, for both the entire period and the reform period, all three policy variables are positively correlated with inland-coastal inequality at the $1 \%$ significance level. The correlations are rather strong, especially for the reform period. Second, for the pre-reform period, GLOBAL is negatively but insignificantly correlated with ICGAP. This is not surprising because China is almost an isolated economy before the reform. MARKET (NSOEPR) is negatively correlated with ICGAP but only marginally significant. Third, the correlation coefficients increase greatly in magnitude and in statistical significance from the pre-reform period to the reform period, suggesting that these policy variables are more relevant for the reform period in intensifying the inland-coastal income gap. From an empirical perspective, a structural break may exist in distinguishing different patterns between the pre-reform period and the reform period.

Table 4: correlation matrix

\begin{tabular}{|c|c|c|c|c|c|c|c|c|c|}
\hline & \multicolumn{3}{|c|}{$1952-2004$} & \multicolumn{3}{|c|}{ Pre-reform period: $1952-1977$} & \multicolumn{3}{|c|}{ Reform period: 1978-2004 } \\
\hline & ICGAP & GLOBAL & DECEN & ICGAP & GLOBAL & DECEN & ICGAP & GLOBAL & DECEN \\
\hline \multirow[t]{2}{*}{ GLOBAL } & 0.687 & & & -0.301 & & & 0.849 & & \\
\hline & {$[0.000]$} & & & {$[0.136]$} & & & {$[0.000]$} & & \\
\hline \multirow[t]{2}{*}{ DECEN } & 0.832 & 0.737 & & 0.632 & -0.196 & & 0.762 & 0.873 & \\
\hline & {$[0.000]$} & {$[0.000]$} & & [0.001] & {$[0.337]$} & & {$[0.000]$} & {$[0.000]$} & \\
\hline MARKET & 0.417 & 0.821 & 0.324 & -0.380 & 0.615 & -0.730 & 0.872 & 0.951 & 0.927 \\
\hline (NSOEPR) & {$[0.002]$} & {$[0.000]$} & {$[0.018]$} & {$[0.055]$} & {$[0.001]$} & {$[0.000]$} & {$[0.000]$} & {$[0.000]$} & {$[0.000]$} \\
\hline
\end{tabular}

Note: All variables are in logarithms. Figures in square brackets are $p$-values.

Fig. 5 shows the scatter plots between three policy variables and ICGDP (in logs), together with both linear regression line and kernel fit. All the plots display a clear and positive relationship between ICGDP and its possible policy determinants. Therefore, any or all of them have the potential to explain

${ }^{9}$ In China, local collected revenues generally were not spent locally, so they did not reflect local fiscal autonomy. 
the income gap between inland and coastal regions. These relationships are confirmed by the econometric regressions reported in Table 5.

Figure 5: Linear fit and kernel fit between ICGAP and its determinants
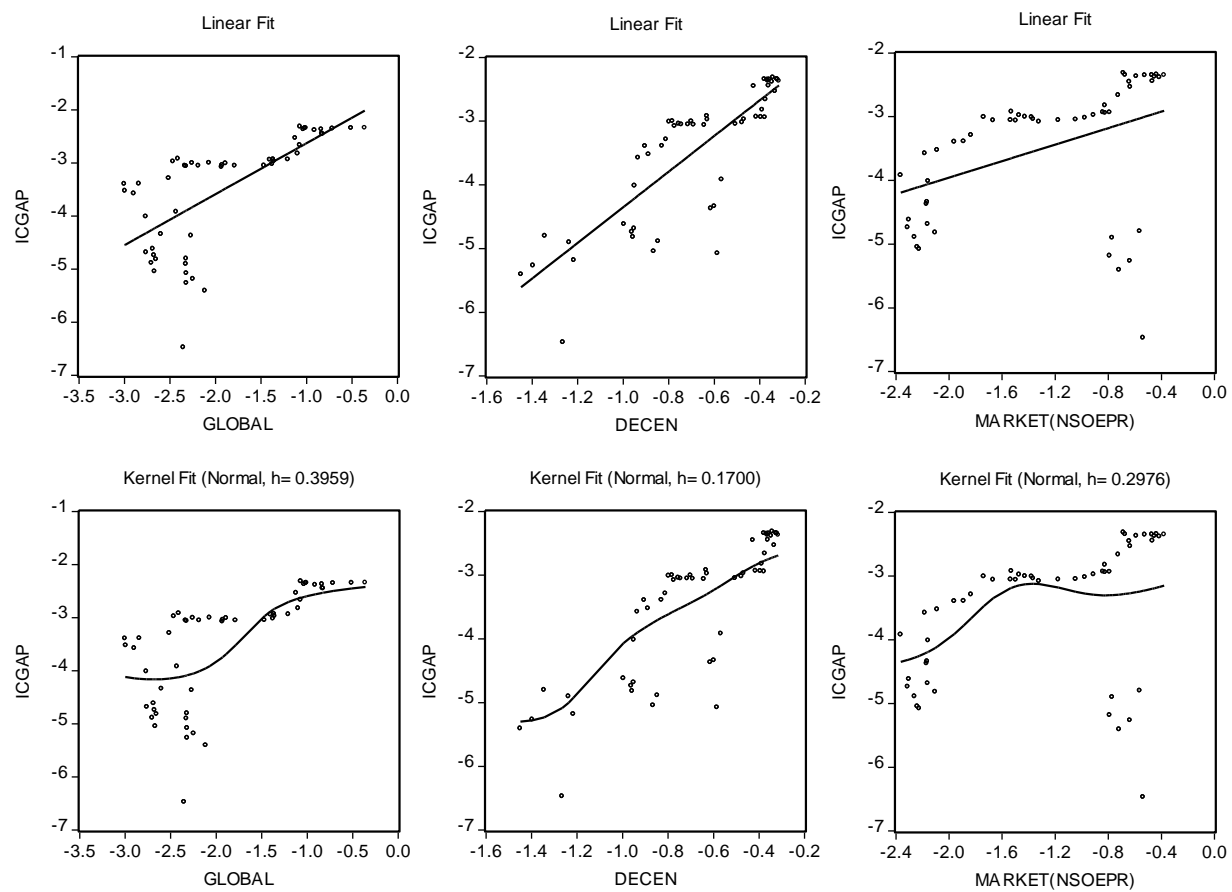

As is well known, the time-series regressions are confronted with a number of econometric difficulties, such as autocorrelation, structural breaks and non-stationary variables. If there is autocorrelation in the data, the OLS estimates will still be unbiased, but the standard errors will be wrong, leading to improper inferences. We use the Durbin-Watson test to detect autocorrelation in our models, and if this is the case, we use the Prais-Winsten estimator to obtain the correct standard errors.

If there are structural breaks in the data-generating process, the estimated parameters are not stable across various subsamples of the data. Moreover, the presence of structural breaks can bias the test results toward a non-rejection of the unit root, and therefore distort the standard tests of cointegration (Gregory and Hansen, 1996). While some statistical procedures can be used to locate of the possible structural breaks ${ }^{10}$, researchers often a priori expect a structural break from a theoretical foundation, such as a war, a regime switching or an oil shock. Within the China's context, there may be a break point at the beginning of the economic reforms in the late 1970s (Li, 2000; Kanbur and Zhang, 2004). As Table 5 shows, the Chow tests indicate a significant break in 1978. In such circumstance, we introduce a period dummy, D, to Eq.(4), yielding:

Eq.(5) $\quad \operatorname{ICGAP}_{\mathrm{t}}=\mathrm{c}+\mathrm{c}^{\prime} \mathrm{D}+\left(\varphi+\varphi^{\prime} \mathrm{D}\right) \mathrm{X}_{\mathrm{t}-1}+\varepsilon_{\mathrm{t}}$

where $\mathrm{D}=1$ for the reform period 1978-2004, and $\mathrm{D}=0$ otherwise, $\mathrm{X}$ is a vector comprising GLOBAL, DECEN and MARKET, and $\varphi$ is their coefficients to estimate. The results on Eq.(5) are reported in columns (2) and (4) in Table 5.

\footnotetext{
${ }^{10}$ See, for example, Andrew (1993) and Hansen (2000).
} 
Finally, if our series are non-stationary, a cointegration relationship should exist to ensure the presence of long run relationship between the levels of the variables. Otherwise, regressions can be spurious and economically meaningless because of the common trends shared by the variables. We first carry out the ADF unit root tests on all our variables to determine their order of integration. As Table 6 shows, all variables are first difference stationary and therefore contain a unit root. A long run relationship between ICGAP and policy variables will exist only if they are cointegrated. We adopt two tests for cointegration: one is residual-based KPSS test and the other is Johansen cointegration test. The evidence from both tests favors the hypothesis of cointegration, as shown in the bottom of Table 5 .

As Table 5 shows, during the pre-reform period 1952-1977, DECEN have a positive and highly significant effect on ICGAP, while GLOBAL only have a marginally significant effect at the $10 \%$ level.

MARKET even exhibits a negative coefficient though it is statistically insignificant. However, for the reform period 1978-2004, the signs of GLOBAL, DECEN and MARKET are positive and statistically significant, which is consistent with our theoretical arguments. Therefore, more openness, greater decentralization, and stronger marketization tend to intensify the income inequality between inland and coastal regions in post-reform China.

Table 5: Time-series estimations

Dependent variable: ICGAP

(1)

(2)

(3)

(4)

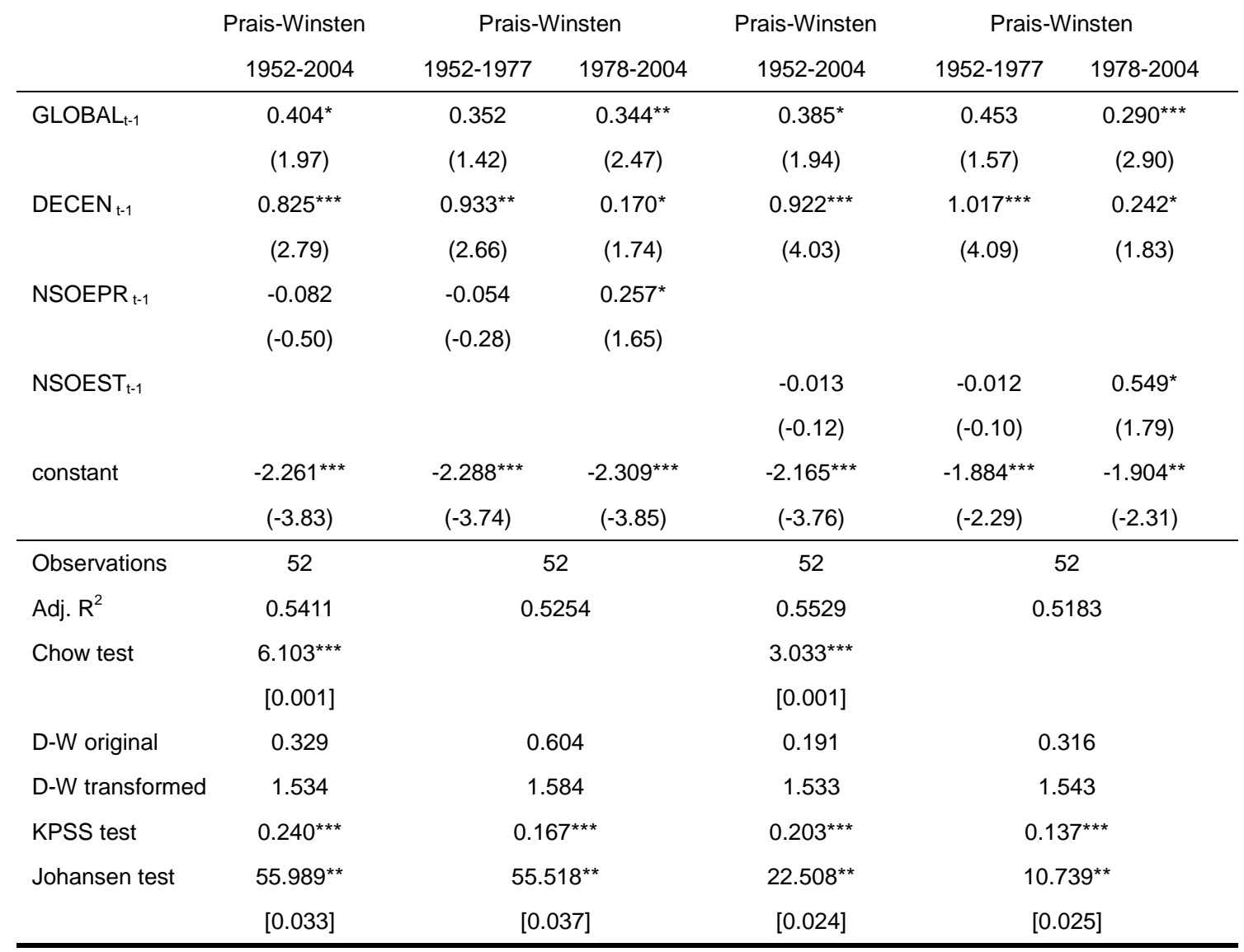

Note: All the variables are in logarithms. Figures in parentheses are $t$-statistics. Figures in square brackets are $p$-values of the corresponding tests. The null hypothesis of the Chow breakpoint test is that there is no structural break in 1978. The KPSS cointegration test has cointegration as the null hypothesis, and the critical values to reject the null are respectively $0.739,0.463$ and 0.347 at the $10 \%, 5 \%$ and $1 \%$ significance level. Figures in the Johansen 
cointegration test are trace statistics. ${ }^{* \star *},{ }^{\star *}$ and ${ }^{*}$ denote significance at the $1 \%, 5 \%$ and $10 \%$ level, respectively.

Table 6: Unit-root tests

\begin{tabular}{llll}
\hline Variables & Model & ADF-statistic & Lag length \\
\hline ADF tests in the levels & & & \\
ICGAP & constant & $-1.078[0.718]$ & 1 \\
GLOBAL & constant and trend & $-1.876[0.652]$ & 1 \\
DECEN & constant and trend & $-2.830[0.193]$ & 0 \\
MARKET(NSOEPR) & constant and trend & $-2.787[0.209]$ & 0 \\
MARKET(NSOEST) & none & $-2.910[0.094]$ & 1 \\
ADF tests in first differences & & & \\
ICGAP & constant no trend & $-10.685[0.000]$ & 0 \\
GLOBAL & none & $-4.733[0.000]$ & 0 \\
DECEN & none & $-7.501[0.000]$ & 0 \\
MARKET(NSOEPR) & constant and trend & $-7.472[0.000]$ & 0 \\
MARKET(NSOEST) & none & $-4.055[0.000]$ & 0 \\
\hline
\end{tabular}

Note: All variables are in logarithms. Figures in square brackets are $p$-values. The Dolado, Jenkinson and Sosvilla-Rivero (1990) procedure is used for choosing the appropriate model. Lag length is determined according to the Schwarz Information criteria (SIC).

\subsection{Results from panel data analysis}

Compared with the above time-series analysis, the analysis based on provincial panel data possesses three advantages. First, the use of panel data not only expands the sample size significantly, but also increases our choices for alternative measures of the variables and for additional controls such as spillover effects. Second, the panel data approach can overcome the omitted variables bias by controlling for time-invariant province-specific fixed effects such as geography. This is particularly important because geographic factors, in addition to policies, play a fundamental role in determining income differences across regions, as argued earlier in Section 3. To the extent that geography has been intertwined with policies, the fixed effect estimator may be more appropriate than the random effect model ${ }^{11}$. In addition, we can also include time-specific fixed effects that do not change across provinces, such as a period dummy to control the collective shocks on all provinces. Finally, the panel data approach provides more flexibility to deal with the endogeneity problem with instrumental variable techniques (IV). For instance, we can use GMM approach to correct endogeneity bias, with lagged regressors acting as instruments for the first-differenced variables.

Inspired by Fu (2004), we adopt a gap model which can be specified as the following log-linear panel data form:

Eq.(6) $\quad \operatorname{ICGAP}_{\text {it }}=\mathrm{c}+\alpha \mathrm{GLOBAL}_{\mathrm{it}}+\beta \mathrm{DECEN}_{\mathrm{it}}+\gamma \mathrm{MARKET}_{\mathrm{it}}+\eta_{\mathrm{i}}+\varepsilon_{\mathrm{it}}$

where $\mathrm{i}$ and $\mathrm{t}$ denote province and year respectively. $\eta_{\mathrm{i}}$ is the province-specific effects representing geography and other factors that are constant over time. For every variable in Eq.(6), we use two measures alternatively. The variables in our estimations are defined as follows:

\footnotetext{
${ }^{11}$ However, with panel data, we can also directly introduce variables of geography in the regressions by using random effect or pooled estimations.
} 
- ICGAP $_{\text {it }}$ is the ratio of the average income of coastal provinces to that of inland province $\mathrm{i}$; when

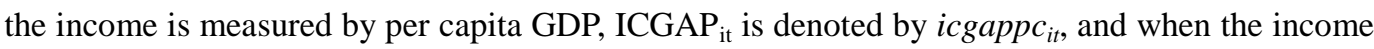
is measured by per worker GDP, ICGAP ${ }_{\text {it }}$ is denoted by icgappw $w_{i t}$.

- GLOBAL $_{i t}$ is the ratio of the average openness in coastal provinces to that in inland province $\mathrm{i}$; when the openness is measured by foreign trade volume (imports plus exports), GLOBAL is $_{\text {it }}$ denoted by trade $_{i t}$, and when the openness is measured by FDI, GLOBAL $\mathrm{it}_{\mathrm{it}}$ is denoted by $f d i_{i t}$.

- DECEN $_{\mathrm{it}}$ is the ratio of the average degree of fiscal decentralization of coastal provinces to that of inland province $\mathrm{i}$; when fiscal decentralization is measured by the ratio of provincial budgetary spending to central budgetary spending, $\mathrm{DECEN}_{\mathrm{it}}$ is denoted by decen $_{i t}$, and when fiscal decentralization is measured by the ratio of provincial per capita budgetary spending to central per capita budgetary spending, $\mathrm{DECEN}_{\mathrm{it}}$ is denoted by decenpc $c_{i t}$.

- MARKET $_{\text {it }}$ is the ratio of average development of non-state sector in coastal provinces to that in inland province $\mathrm{i}$; when the development of non-state sector is measured by the share of non-state enterprises in industrial production, MARKET $_{\text {it }}$ is denoted by $n s o e p r_{i t}$, and when the development of non-state sector is measured by the share of non-state enterprises in total staff and workers, MARKET $_{\text {it }}$ is denoted by nsoest ${ }_{i t}$.

All data are obtained from Comprehensive Statistical Data and Materials on 55 Years of New China (NBS, 2005). The estimations are based on annual data from 1978 to 2004 for 18 inland provinces, with two exceptions. In the early years of the reforms, FDI inflow in China was highly concentrated in several provinces such as Guangdong and Fujian. There are actually no data for most provinces until the mid-1980s. Therefore, our data on $f d i_{i t}$ only cover the period 1987-2004. Data on $n s o e p r_{i t}$ contain the period 1978-2003 because the NBS do not provide the statistical data on the gross value of industrial output by province since 2004 .

As argued earlier, while geography is the exogenous factor in determining income differences across regions, policy variables are assumed to be endogenous fundamental determinants. We apply the Wu-Hausman procedure to test for such endogeneity. Two-years lagged values of regressors and other exogenous variables are used as instrument variables. If endogeneity is present, we apply an IV fixed effects model for estimation (IV-FE); otherwise, we use normal fixed effects model (FE). According to our hypothesis, the individual effects of which geography is a major part should be correlated with other regressors, namely policy variables. Therefore, the fixed effects model is preferred to the random effects model in this paper, though in some cases this hypothesis has not been statistically supported by the Hausman tests. For comparison, we also present the results using the GMM method.

Table 7 reports the estimation results with icgapp $_{i t}$ as the dependent variable ${ }^{12}$. Because the $\mathrm{Wu}$-Hausman tests indicate significant endogeneity between icgapp $_{i t}$ and policy variables in all cases, the IV-FE estimator is preferred. As expected, all three policy variables enter the regression positively and highly significant at the $1 \%$ level, regardless of the different proxies for them. Since we have controlled for the endogeneity associated with them, the results suggest that policies with respect to globalization, decentralization and marketization have causal and positive impacts on inland-coastal income gap. For example, the results in column (1) of Table 7 indicate that a one percent increase in

\footnotetext{
${ }^{12}$ Due to the large difference in terms of time period between $f d i_{i t}$ and the other variables, we do not report the results from the specification with $f d i_{i t}$. The results are essentially similar and available upon request.
} 
the average trade volume in coastal provinces relative to that in inland regions would increase the income gap by about 0.094 percent. Similarly, a one percent increase in the decentralization gap and in the marketization gap would increase the income gap between coastal and inland regions by about 0.077 and 0.136 percent, respectively. In addition, the (unreported) estimates for the province-specific effects are all significant at the 5\% level at least, suggesting that geographic factors also matter in explaining regional income gap. Finally, the GMM results tell an almost identical story, except that the estimated coefficients lose the significance in a few cases.

When another measure of income gap, icgappw $w_{i t}$, is used as the dependent variable, we obtain very similar results, as reported in Table 8. Moreover, the coefficient estimates on all three policy variables appear to be greater in magnitude than their counterparts in Table 7. For example, from column (1) in Table 8, the coefficient of openness gap on income gap is 0.119 , as compared to previous estimate (0.094) in Table 7. The same holds true for the estimates on the other two policy variables. This result suggests that policies may exert a stronger and more direct influence on the inland-coastal inequality in terms of per capita worker. Such stronger influence seems to be neutralized in some extent by employment and demographic factors so that the actual effects of the policies on inland-coastal inequality in terms of per capita GDP become weaker.

Table 7: Panel data estimations of Eq.(6)

\begin{tabular}{|c|c|c|c|c|c|c|c|c|}
\hline \multicolumn{9}{|c|}{ Dependent variable: icgappc $c_{i t}$} \\
\hline & (1) & (2) & (3) & (4) & (5) & (6) & (7) & (8) \\
\hline & IV-FE & IV-FE & IV-FE & IV-FE & GMM & GMM & GMM & GMM \\
\hline \multirow[t]{2}{*}{ trade $_{i t}$} & $0.094^{\star * *}$ & $0.090^{\star * \star}$ & $0.139^{\star * *}$ & $0.141^{\star \star *}$ & $0.093^{\star * *}$ & $0.095^{\star \star *}$ & $0.168^{* \star *}$ & $0.181^{* * *}$ \\
\hline & $(4.64)$ & $(4.47)$ & $(6.70)$ & $(6.70)$ & (3.05) & (3.03) & $(4.56)$ & $(6.54)$ \\
\hline \multirow[t]{2}{*}{ decen $_{i t}$} & $0.077^{* * *}$ & & $0.190^{* \star *}$ & & 0.054 & & $0.243^{* * *}$ & \\
\hline & $(2.78)$ & & $(10.43)$ & & $(1.21)$ & & $(4.41)$ & \\
\hline \multirow[t]{2}{*}{ decenpc $c_{i t}$} & & $0.062^{* *}$ & & $0.179^{* * *}$ & & 0.035 & & $0.237^{* * *}$ \\
\hline & & $(2.36)$ & & $(9.85)$ & & $(0.90)$ & & $(4.96)$ \\
\hline \multirow[t]{2}{*}{ nsoepr $r_{i t}$} & $0.136^{\star \star *}$ & $0.146^{\star * *}$ & & & $0.203^{\star * *}$ & $0.209^{* \star *}$ & & \\
\hline & $(6.07)$ & $(6.76)$ & & & $(6.98)$ & $(5.02)$ & & \\
\hline \multirow[t]{2}{*}{ nsoest $_{i t}$} & & & $0.266^{* * *}$ & $0.255^{\star \star \star}$ & & & $0.326^{\star *}$ & 0.163 \\
\hline & & & $(3.90)$ & (3.64) & & & $(2.27)$ & $(1.06)$ \\
\hline \multirow[t]{2}{*}{$\mathrm{F}$ test FE } & $112.65^{\star \star \star}$ & $95.08^{\star \star *}$ & $94.31^{\star * *}$ & $95.41^{\star \star *}$ & & & & \\
\hline & {$[0.000]$} & [0.000] & {$[0.000]$} & {$[0.000]$} & & & & \\
\hline \multirow[t]{2}{*}{ Wu-Hausman } & $6.15^{\star \star *}$ & $5.81^{\star \star \star}$ & $9.00^{\star \star \star}$ & $7.74^{\star \star \star}$ & & & & \\
\hline & [0.000] & [0.001] & {$[0.000]$} & {$[0.000]$} & & & & \\
\hline Hansen test & & & & & {$[1.000]$} & {$[1.000]$} & [1.000] & [1.000] \\
\hline $\mathrm{AR}(2)$ & & & & & [0.345] & [0.315] & [0.927] & [0.865] \\
\hline Observations & 426 & 426 & 443 & 443 & 462 & 462 & 479 & 479 \\
\hline Provinces & 18 & 18 & 18 & 18 & 18 & 18 & 18 & 18 \\
\hline
\end{tabular}




\begin{tabular}{|c|c|c|c|c|c|c|c|c|}
\hline \multicolumn{9}{|c|}{ Dependent variable: icgappw $w_{i t}$} \\
\hline & (1) & (2) & (3) & (4) & (5) & (6) & (7) & (8) \\
\hline & IV-FE & IV-FE & IV-FE & IV-FE & GMM & GMM & GMM & GMM \\
\hline \multirow[t]{2}{*}{ trade $_{i t}$} & $0.119^{* * *}$ & $0.119^{\star * *}$ & $0.204^{\star * *}$ & $0.210^{\star * *}$ & $0.163^{* * *}$ & $0.146^{* * *}$ & $0.262^{\star \star *}$ & $0.254^{* * *}$ \\
\hline & $(4.95)$ & $(4.98)$ & $(8.14)$ & $(8.30)$ & $(4.70)$ & $(3.27)$ & $(4.56)$ & $(5.42)$ \\
\hline \multirow[t]{2}{*}{ decen $_{i t}$} & $0.137^{\star \star \star}$ & & $0.326^{\star * *}$ & & 0.072 & & $0.369^{\star \star \star}$ & \\
\hline & $(3.86)$ & & $(14.53)$ & & $(1.53)$ & & $(5.81)$ & \\
\hline \multirow[t]{2}{*}{ decenpc $_{i t}$} & & $0.128^{\star \star *}$ & & $0.316^{\star * *}$ & & 0.093 & & $0.363^{* * *}$ \\
\hline & & (3.78) & & $(14.09)$ & & $(1.68)$ & & $(5.56)$ \\
\hline \multirow[t]{2}{*}{ nsoepr $r_{i t}$} & $0.214^{\star * *}$ & $0.221^{* * *}$ & & & $0.292^{* * *}$ & $0.286^{* * *}$ & & \\
\hline & $(7.15)$ & $(7.63)$ & & & $(6.96)$ & $(4.70)$ & & \\
\hline \multirow[t]{2}{*}{ nsoest $_{i t}$} & & & $0.269^{\star \star *}$ & $0.316^{\star \star \star}$ & & & $0.468^{\star *}$ & 0.223 \\
\hline & & & $(3.23)$ & $(2.92)$ & & & $(2.77)$ & $(1.19)$ \\
\hline \multirow[t]{2}{*}{$F$ test FE } & $120.47^{\star \star *}$ & $107.35^{\star \star *}$ & $94.60^{* * *}$ & $110.48^{\star \star *}$ & & & & \\
\hline & {$[0.000]$} & {$[0.000]$} & {$[0.000]$} & {$[0.000]$} & & & & \\
\hline \multirow[t]{2}{*}{ Wu-Hausman } & $13.07^{\star \star *}$ & $12.83^{* * *}$ & $10.72^{* * *}$ & $9.63^{\star \star *}$ & & & & \\
\hline & {$[0.000]$} & {$[0.000]$} & {$[0.000]$} & {$[0.000]$} & & & & \\
\hline Hansen test & & & & & {$[1.000]$} & [1.000] & [1.000] & [1.000] \\
\hline $\mathrm{AR}(2)$ & & & & & [0.439] & {$[0.456]$} & {$[0.641]$} & [0.964] \\
\hline Observations & 426 & 426 & 443 & 443 & 462 & 462 & 479 & 479 \\
\hline Provinces & 18 & 18 & 18 & 18 & 18 & 18 & 18 & 18 \\
\hline
\end{tabular}

Note: All the variables are in logarithms. Figures in parentheses are heteroskedasticity-consistent $t$-statistics. Figures in square brackets are $p$-values of the corresponding tests. ${ }^{* * *},{ }^{* *}$ and ${ }^{*}$ denote significance at the $1 \%, 5 \%$ and $10 \%$ level, respectively.

Recent studies emphasized the role of the spillover effects from coastal to inland regions in China (Ying, 2000; Brun et al., 2002; Fu, 2004). Indeed, in the early stage of economic reforms, the central government has encouraged some regions to "get rich first" and emphasized coastal development, expecting that the growth centers in the coastal region would produce diffusion to the interior and ultimately stimulate the prosperity of the whole country (NCDR, 1994). However, it is agreed that the spillover effects are insufficient or limited, if not negligible. Moreover, the spillover effects from the growth centers to inland areas diminish as distance increases. Thus, it is helpful to check the robustness of our empirical results by controlling the spillover effects.

In addition, there may have been some unobservable shocks over time that are common to all the provinces, such as national mobilization for economic acceleration in the 1990s, which also have an influence on the income gap between inland and coastal regions. We further include a period dummy in our estimations. Consequently, the estimation equation can be re-expressed as follows:

Eq.(7) $\quad$ ICGAP $_{\mathrm{it}}=\mathrm{c}+\alpha \mathrm{GLOBAL}_{\mathrm{it}}+\beta \mathrm{DECEN}_{\mathrm{it}}+\gamma \mathrm{MARKET}_{\mathrm{it}}+\delta$ diffusion $_{i t}+\theta d 9100+\eta_{\mathrm{i}}+\varepsilon_{\mathrm{it}}$ where diffusion $_{i t}$ is the spillover effects, and $d 9100$ is the period dummy which is equal to 1 for 1991-2000 and 0 otherwise. We follow Fu (2004, pp.157) to construct the spillover effects variable as 
follows ${ }^{13}$ :

Eq.(8) $\quad$ diffusion $_{i t}=\sum \omega_{\mathrm{jt}}\left(\mathrm{x}_{\mathrm{j} t} / \mathrm{d}_{\mathrm{ij}}\right)$

where $\omega_{\mathrm{jt}}$ is the share of exports of coastal province $\mathrm{j}$ in total exports of all the coastal provinces, $\mathrm{x}_{\mathrm{jt}}$ is the export growth rate of coastal province $\mathrm{j}$, and $\mathrm{d}_{\mathrm{ij}}$ is the geographical distance between inland province $\mathrm{i}$ and coastal province $\mathrm{j}$ measured by the distance between their capital cities. We expect the coefficient on diffusion $_{i t}$ is negative since the spillover effects may help close the regional inequality.

Table 9 report results for the income gap measured by $i c g a p p c_{i t}$. For brevity, we do not report the GMM results. In columns (1)-(4) only policy variables and diffusion ${ }_{i t}$ are included. In columns (5)-(8), $d 9100$ is further added in the estimations. Three results are worth highlighting. First, the coefficient estimates on three policy variables are little changed relative to the previous estimates in Table $7^{14}$. They remain positive and highly significant at the $1 \%$ level. Second, as expected, diffusion ${ }_{i t}$ enters the regression negatively and significantly. In particular, the magnitude of its coefficients turns to be rather modest. For example, look at column (5), a one percent increase in spillover effects would only reduce the income gap by about 0.012 percent. Therefore, the equalizing effects of the spillovers appear to be insufficient to offset the exaggerating effect of government policies on regional inequality. These results are consistent with those reported by previous studies (Brun et al., 2002; Fu, 2004). Third, the coefficients on $d 9100$ are positive and significantly at the $1 \%$ level, indicating that the 1990 s witnessed a higher regional inequality.

Finally, we evaluate the sensibility of the results to the use of icgappw $w_{i t}$ as proxy for income gap (Table 10). All variables perform as expected. In comparison with their counterparts in Table 9, the coefficients on three policy variables become larger, again confirming that policies have a stronger impact on per worker GDP gap than per capita GDP gap across regions. The magnitude of the coefficients on diffusion ${ }_{i t}$ is little changed, while coefficients on $d 9100$ turn to be slightly smaller.

Table 9: Panel data estimations of Eq.(7)

Dependent variable: icgappc $_{i t}$

\begin{tabular}{|c|c|c|c|c|c|c|c|c|}
\hline & (1) & (2) & (3) & (4) & (5) & (6) & (7) & (8) \\
\hline & IV-FE & IV-FE & IV-FE & IV-FE & IV-FE & IV-FE & IV-FE & IV-FE \\
\hline \multirow[t]{2}{*}{ trade $_{i t}$} & $0.095^{\text {** }}$ & $0.091^{* * *}$ & $0.140^{* \star *}$ & $0.142^{* * *}$ & $0.069^{* * *}$ & $0.063^{* * *}$ & $0.139^{* * *}$ & $0.139^{* * *}$ \\
\hline & $(4.71)$ & $(4.53)$ & (6.91) & (6.92) & (3.68) & (3.41) & $(7.00)$ & (6.92) \\
\hline \multirow[t]{2}{*}{$\operatorname{decen}_{i t}$} & $0.087^{\star \star *}$ & & $0.195^{\star \star *}$ & & -0.026 & & $0.117^{\star \star \star}$ & \\
\hline & (3.12) & & (10.72) & & $(-1.09)$ & & (5.72) & \\
\hline \multirow[t]{2}{*}{ decenpc $_{\text {it }}$} & & $0.072^{* * *}$ & & $0.184^{* * *}$ & & $-0.038^{\star}$ & & $0.101^{* * *}$ \\
\hline & & (2.69) & & (10.16) & & $(-1.65)$ & & (5.06) \\
\hline
\end{tabular}

\footnotetext{
${ }^{13}$ There can be different measures for the spillover effects according to the underlying mechanisms. For instance, Brun et al. (2002) argue that the spillover effects can result from three externalities: demand side externalities (through increasing demand for products of the inland regions), trade externalities (through reducing transaction cost and enhancing domestic trade), and supply side externalities (through diffusion of technological knowledge and managerial skills). The supply spillovers will prevail in the long run, which can be channeled by inter-regional trade and FDI. However, due to shorter time period associated with FDI data, we rely on exports data to construct our variable of spillovers.

${ }^{14}$ Only two exceptions arise: the first is in column (5) where the coefficient on decen $_{i t}$ is negative but insignificant, and the second is in column (6) where the coefficient on decenpr $r_{i t}$ is negative and marginally significant.
} 


\begin{tabular}{|c|c|c|c|c|c|c|c|c|}
\hline nsoepr ${ }_{i t}$ & $\begin{array}{c}0.124^{* * *} \\
(5.55)\end{array}$ & $\begin{array}{l}0.134^{* * *} \\
(6.24)\end{array}$ & & & $\begin{array}{c}0.158^{* * *} \\
(7.57)\end{array}$ & $\begin{array}{c}0.164^{* * *} \\
(8.14)\end{array}$ & & \\
\hline nsoest $_{i t}$ & & & $\begin{array}{c}0.219^{* * *} \\
(3.23)\end{array}$ & $\begin{array}{c}0.207^{\star * *} \\
(2.98)\end{array}$ & & & $\begin{array}{c}0.172^{\star *} \\
(2.50)\end{array}$ & $\begin{array}{c}0.161^{* *} \\
(2.29)\end{array}$ \\
\hline diffusion $_{\text {it }}$ & $\begin{array}{c}-0.022^{\star * *} \\
(-3.28)\end{array}$ & $\begin{array}{c}-0.022^{\star * *} \\
(-3.21)\end{array}$ & $\begin{array}{c}-0.026^{\star * *} \\
(-3.66)\end{array}$ & $\begin{array}{c}-0.027^{\star * *} \\
(-3.61)\end{array}$ & $\begin{array}{l}-0.012^{*} \\
(-1.80)\end{array}$ & $\begin{array}{l}-0.011^{*} \\
(-1.76)\end{array}$ & $\begin{array}{l}-0.016^{\star *} \\
(-2.22)\end{array}$ & $\begin{array}{c}-0.015^{* *} \\
(-2.09)\end{array}$ \\
\hline d9100 & & & & & $\begin{array}{c}0.073^{\star \star \star} \\
(6.29)\end{array}$ & $\begin{array}{c}0.073^{\star \star *} \\
(6.38)\end{array}$ & $\begin{array}{c}0.074^{\star \star \star} \\
(5.56)\end{array}$ & $\begin{array}{c}0.080^{\star \star *} \\
(6.11)\end{array}$ \\
\hline$F$ test FE & $\begin{array}{c}112.20^{* \star \star} \\
{[0.000]}\end{array}$ & $\begin{array}{c}95.29^{\star \star \star \star} \\
{[0.000]}\end{array}$ & $\begin{array}{c}95.68^{* \star \star} \\
{[0.000]}\end{array}$ & $\begin{array}{c}98.36^{* * *} \\
{[0.000]}\end{array}$ & $\begin{array}{c}133.03^{\star * *} \\
{[0.000]}\end{array}$ & $\begin{array}{c}101.71^{* * *} \\
{[0.000]}\end{array}$ & $\begin{array}{c}107.77^{\star \star \star} \\
{[0.000]}\end{array}$ & $\begin{array}{c}98.36^{\star * *} \\
{[0.000]}\end{array}$ \\
\hline Wu-Hausman & $\begin{array}{l}6.45^{\star * *} \\
{[0.000]}\end{array}$ & $\begin{array}{l}6.07^{\star * *} \\
{[0.000]}\end{array}$ & $\begin{array}{l}8.42^{\star \star *} \\
{[0.000]}\end{array}$ & $\begin{array}{l}7.39^{\star * *} \\
{[0.000]}\end{array}$ & $\begin{array}{c}2.48^{\star} \\
{[0.060]}\end{array}$ & $\begin{array}{c}2.44^{*} \\
{[0.064]}\end{array}$ & $\begin{array}{l}3.10^{\star \star} \\
{[0.027]}\end{array}$ & $\begin{array}{c}2.34^{*} \\
{[0.073]}\end{array}$ \\
\hline Observations & 422 & 422 & 439 & 439 & 422 & 422 & 439 & 439 \\
\hline Provinces & 18 & 18 & 18 & 18 & 18 & 18 & 18 & 18 \\
\hline
\end{tabular}

Note: All the variables are in logarithms. Figures in parentheses are heteroskedasticity-consistent $t$-statistics. Figures in square brackets are $p$-values of the corresponding tests. ${ }^{* * *},{ }^{* *}$ and ${ }^{*}$ denote significance at the $1 \%, 5 \%$ and $10 \%$ levels, respectively.

Table 10: Panel data estimations of Eq.(7)

\begin{tabular}{|c|c|c|c|c|c|c|c|c|}
\hline \multicolumn{9}{|c|}{ Dependent variable: icgappw $w_{i t}$} \\
\hline & (1) & (2) & (3) & (4) & (5) & (6) & (7) & (8) \\
\hline & IV-FE & IV-FE & IV-FE & IV-FE & IV-FE & IV-FE & IV-FE & IV-FE \\
\hline \multirow[t]{2}{*}{ trade $_{i t}$} & $0.119^{\star * *}$ & $0.119^{\star * *}$ & $0.205^{\star \star \star}$ & $0.211^{* \star *}$ & $0.101^{* * *}$ & $0.100^{\star * \star}$ & $0.204^{* * *}$ & $0.208^{\star * *}$ \\
\hline & (5.04) & (5.06) & $(8.40)$ & $(8.56)$ & $(4.43)$ & $(4.39)$ & (8.46) & (8.55) \\
\hline \multirow[t]{2}{*}{ decen $_{i t}$} & $0.145^{\star \star \star}$ & & $0.330^{\star \star \star}$ & & $0.066^{\star *}$ & & $0.267^{\star \star \star}$ & \\
\hline & $(4.09)$ & & (14.94) & & $(2.11)$ & & $(10.26)$ & \\
\hline \multirow[t]{2}{*}{ decenp $_{i t}$} & & $0.136^{\star * *}$ & & $0.321^{* * *}$ & & $0.059^{*}$ & & $0.249^{* * *}$ \\
\hline & & (3.99) & & $(14.51)$ & & $(1.95)$ & & $(9.73)$ \\
\hline \multirow[t]{2}{*}{ nsoepr $r_{i t}$} & $0.203^{\star \star *}$ & $0.210^{\star * *}$ & & & $0.227^{\star \star \star}$ & $0.231^{* * *}$ & & \\
\hline & $(6.86)$ & $(7.36)$ & & & (8.38) & (8.77) & & \\
\hline \multirow[t]{2}{*}{ nsoest $_{i t}$} & & & $0.212^{\star *}$ & $0.193^{\star *}$ & & & $0.174^{\star *}$ & $0.153^{*}$ \\
\hline & & & $(2.54)$ & $(2.24)$ & & & $(2.03)$ & $(1.76)$ \\
\hline \multirow[t]{2}{*}{ diffusion $_{\text {it }}$} & $-0.022^{\star * \star}$ & $-0.022^{\star * *}$ & $-0.030^{\star \star *}$ & $-0.030^{\star * *}$ & $-0.015^{\star}$ & $-0.014^{*}$ & $-0.021^{* *}$ & $-0.020^{* *}$ \\
\hline & $(-2.74)$ & $(-2.68)$ & $(-3.43)$ & $(-3.38)$ & $(-1.81)$ & $(-1.76)$ & $(-2.37)$ & $(-2.22)$ \\
\hline \multirow[t]{2}{*}{$d 9100$} & & & & & $0.050^{* * *}$ & $0.051^{* * *}$ & $0.061^{* * *}$ & $0.069^{* \star *}$ \\
\hline & & & & & (3.27) & (3.31) & $(3.40)$ & (3.88) \\
\hline \multirow[t]{2}{*}{$\mathrm{F}$ test $\mathrm{FE}$} & $119.25^{\star * *}$ & $107.39^{* * *}$ & $94.50^{* * *}$ & $112.41^{* * *}$ & $129.21^{* * *}$ & $108.58^{\star \star \star}$ & $102.04^{\star \star \star}$ & $100.25^{\star * *}$ \\
\hline & {$[0.000]$} & {$[0.000]$} & {$[0.000]$} & {$[0.000]$} & {$[0.000]$} & {$[0.000]$} & {$[0.000]$} & [0.001] \\
\hline \multirow[t]{2}{*}{ Wu-Hausman } & $12.80^{\star \star \star}$ & $12.56^{\star \star *}$ & $10.32^{* * *}$ & $9.44^{\star * *}$ & $9.08^{\star * *}$ & $9.08^{\star * *}$ & $4.29^{\star \star \star}$ & $3.31^{* *}$ \\
\hline & {$[0.000]$} & {$[0.000]$} & {$[0.000]$} & {$[0.000]$} & {$[0.000]$} & {$[0.000]$} & [0.005] & {$[0.020]$} \\
\hline Observations & 422 & 422 & 439 & 439 & 422 & 422 & 439 & 439 \\
\hline Provinces & 18 & 18 & 18 & 18 & 18 & 18 & 18 & 18 \\
\hline
\end{tabular}

Note: All the variables are in logarithms. Figures in parentheses are heteroskedasticity-consistent $t$-statistics. Figures in square brackets are $p$-values of the corresponding tests. ${ }^{* * *},{ }^{* *}$ and ${ }^{*}$ denote significance at the $1 \%, 5 \%$ and $10 \%$ levels, respectively. 


\section{Conclusion}

Growing inequality between inland and coastal regions in post-reform China has attracted considerable scholarly attention. While there is voluminous literature on the sources of the rising inequality, few of them have captured the fundamental reasons within a systematical framework. This paper aims at filling this gap by empirically investigating the deep-rooted causes of the widening inland-coastal inequality in China during the reform period 1978-2004.

We build on the economic development theory by Rodrik et al. (2004) and modify it according to the special context of the Chinese economy. Three policy variables, namely globalization, decentralization and marketization, are argued to be the fundamental forces responsible for the widening inland-coastal inequality. While these three variables have strongly influenced regional development in China, they are either neglected or studied in an indirect way in the existing literature. We directly estimate the contributions of these three variables on the inland-coastal income gap, using both time-series and panel data. In the former case, the inter-region component of total Theil index is used as the dependent variable, while in the latter case, a gap model is applied. The empirical results derived from both cases provide strong evidence in support of our arguments. Even after controlling for endogeneity and fixed effects (mainly geography), we find all three policy variables have causal and significantly positive impacts on the inland-coastal income gap. This finding turns to be quite robust to the use of different estimation methods, alternative proxies for policies and regional income, and the inclusion of other controls. Furthermore, we find significant but economically small spillover effects from the coastal to inland provinces. While acknowledging the policy determinants, we find that geographic factors also play a significant role in determining the inland-coastal inequality.

As a large and diverse country, China always faces the challenges of equitable regional development and national economic integration. Indeed in recent years the central government has made substantial efforts to control regional inequality. Many inland areas have been opened up for foreign investment, and substantial resources and investment have been allocated to the interior. However, China is no longer a planned country, and the control of the central government has declined. Regional inequality in China is not only determined by the geographical conditions but also by the intricate interplay among the state, local government, domestic and foreign investors. Our results indicate the policies are thus far inequality-exaggerating. While geographical constraints are exogenous and impossible to overcome completely, more efforts should be made to improve regional development policies in China. To effectively reduce the inland-coastal inequality, more attention should be paid to the policies on facilitating non-state sectors, promoting investment returns, and reforming regional planning institutions in the inland regions. It is also crucial to remove institutional barriers and create a more flexible environment so as to enhance the spillover effects between the inland and coastal regions.

\section{References}

Andrews, D. W. K. (1993). Tests for parameter instability and structural change with unknown change point. Econometrica, 61(4), pp.821-856. 
Bao, S., Chang, G. H., Sachs, J. D., and Woo, W. T. (2002). Geographic factors and China's regional development under market reforms, 1978-1998. China Economic Review, 13(1), pp.89-111.

Bhalla, A., Yao, S., and Zhang, Z. (2003). Causes of inequalities in China, 1952 to 1999. Journal of International Development, 15(3), pp.1-17.

Brun, J. F., Combes, J. L., and Renard, M. F. (2002). Are there spillover effects between coastal and noncoastal regions in China? China Economic Review, 13(2-3), pp.161-169.

Cai, F., Wang, D., and Du, Y. (2002). Regional disparity and economic growth in China: The impact of labor market distortions. China Economic Review, 13(2), pp.197-212.

Chen, B., and Feng, Y. (2000). Determinants of economic growth in China: Private enterprises, education and openness. China Economic Review, 11(1), pp.1-15.

Chen, J., and Fleisher B. M. (1996). Regional income inequality and economic growth in China. Journal of Comparative Economics, 22(2), pp.141-164.

Coulter, P. B. (1989). Measuring Inequality: A Methodological Handbook. Boulder, Colorado: Wesview Press.

Démurger S., Sachs, J. D., Woo, W. T., Bao, S., and Chang, G. (2002). The relative contributions of location and preferential policies in China's regional development: Being in the right place and having the right incentives. China Economic Review, 13(4), pp.444-465.

Démurger, S. (2001). Infrastructure development and economic growth: An explanation for regional disparities in China? Journal of Comparative Economics, 29(1), pp.95-117.

Dolado, J. J., Jenkinson, T., and Sosvilla-Rivero, S. (1990). Cointegration and unit roots. Journal of Economic Surveys, 4, pp.249-273.

Fleisher, B., and Chen, J. (1997). The coast-noncoast income gap, productivity, and regional economic policy in China. Journal of Comparative Economics, 25(2), pp.220-236.

$\mathrm{Fu}, \mathrm{X}$. (2004). Limited linkages from growth engines and regional disparities in China. Journal of Comparative Economics, 32(1), pp.148-164.

Gregory, A. W., and Hansen, B. E. (1996). Residual-based tests for cointegration in models with regime shifts. Journal of Econometrics, 70, pp.99-126.

Hansen, B. E. (2000). Sample splitting and threshold estimation. Econometrica, 68(3), pp.575-603.

Hao, R. (2007). Sources of income differences across Chinese provinces during the reform period: A development accounting exercise. CERDI Working Paper 2007/23, Univeristé d'Auvergne, France.

Hao, R. (2008). Opening up, marketization reforms, and convergence clubs in China. Asian Economic Journal, 22(2), forthcoming.

Jian, T. L., Sachs, J. D., and Warner, A. M. (1996). Trends in regional inequality in China. China Economic Review, 7(1), pp.1-21.

Kanbur, R., and Zhang, X. (1999). Which regional inequality? The evolution of rural-urban and inland-coastal inequality in China from 1983 to 1995. Journal of Comparative Economics, 27, pp.686-701.

Kanbur, R., and Zhang, X. (2004). Fifty years of regional inequality in China: A journey through central planning, reform, and openness. WIDER Research Paper No. 2004/50, United Nations University, Finland.

Krugman, P. (1995). Development, Geography, and Economic Theory. Cambridge MA: The MIT Press.

Laurenceson, J., and Chai, J. C. H. (2000). The economic performance of China's state-owned industrial enterprises. Journal of Contemporary China, 9, pp.21-39.

Lee, J. (2000). Changes in the sources of China's regional inequality. China Economic Review, 11(3), pp.232-245.

Li, X-M. (2000). The Great Leap Forward, economic reforms, and the unit root hypothesis: Testing for breaking trend functions in China's GDP data. Journal of Comparative Economics, 27, pp.814-827.

Lin, J. Y., Wang, G., and Zhao, Y. (2004). Regional inequality and labor transfers in China. Economic Development and Cultural Change, 52(3), pp.587-603. 
Liu, T., and Li, K-W. (2006). Disparity in factor contributions between coastal and inner provinces in post-reform China, China Economic Review, 17(4), pp.449-470.

Lu, D. (2008). China's regional income disparity: An alternative way to think of the sources and causes. Economics of Transition, 16(1), pp.31-58.

Lyons, T. P. (1991). Interprovincial disparities in China: Output and consumption. Economic Development and Cultural Change, 39(3), pp.471-506.

National Bureau of Statistics of China. (2005). Comprehensive Statistical Data and Materials on 55 years of New China, Beijing: China Statistics Press.

National Center for Development and Research. (1994). China's Regional Cooperation and Development Strategy. Beijing: China's Economic Press.

National Economic Research Institute. (2001). NERI Index of Marketization of China's Provinces 2000. Beijing: Economic Science Press.

Naughton, B. (1988). The third front: Defense industrialization in the Chinese interior. The China Quarterly, 115, pp.351-386.

Poncet, S. (2003). Measuring Chinese domestic and international integration. China Economic Review, 14(1), pp.1-22.

Raiser, M. (1998). Subsidizing inequality: Economic reforms, fiscal transfer and convergence across Chinese provinces. Journal of Development Studies, 34(3), pp.1-26.

Rodrik, D., Subramanian, A., and Trebbi, F. (2004). Institutions rule: The primacy of institutions over geography and integration in economic development. Journal of Economic Growth, 9, pp.131-165.

Rozelle, S. (1994). Rural industrialization and increasing inequality: Emerging patterns in China's reforming economy. Journal of Comparative Economics, 19(3), pp.362-391.

Sachs, J. D., Mellinger, A., and Gallup, J. (2000). Climate, Coastal Proximity, and Development. In Clark, G. L., Feldman, M. P., and Gertler, M. S. (eds.), Oxford Handbook of Economic Geography. Oxford University Press.

Shankar, R., and Shah, A. (2003). Bridging the economic divide within countries: A scorecard on the performance of regional policies in reducing regional income disparities. World Development, 31(8), pp.1421-1441.

Shorrocks, A. F. (1980). The class of additively decomposable inequality measures. Econometrica, 48(3), pp.613-625.

Song, S., Chu, G. S.-F., and Cao, R. (2000). Intercity regional disparity in China. China Economic Review, 11(3), pp.246-261.

Tsui, K. Y. (1993). Decomposition of China's regional inequalities. Journal of Comparative Economics, 17(3), pp.600-627.

Wei, Y. D. (1996). Fiscal systems and uneven regional development in China, 1978-1991. Geoforum, 27(3), pp.329-344.

Wei, Y. D. (2002). Multiscale and multimechanisms of regional inequality in China: Implications for regional policy. Journal of Contemporary China, 11(30), pp.109-124.

Wei, Y. D. (2004). Trajectories of ownership transformation in China: Implications for uneven regional development. Eurasian Geography and Economics, 45(2), pp.90-113.

Wei, Y. D., and Ma, L. J. C. (1996). Changing patterns of spatial inequality in China, 1952-1990. Third World Planning Review, 18(2), pp.177-191.

Wen, M. (2007). Foreign direct investment, regional market conditions and regional development: A panel study on China. Economics of Transition, 15(1), pp.125-151.

Yang, D. T. (2002). What has caused regional inequality in China? China Economic Review, 13(4), pp.331-334.

Ying, L. G. (2000). Measuring the spillover effects: Some Chinese evidence. Paper in regional Science, 79, pp.75-89. 
Zhang, J. (2007). China's economic growth: Trajectories and evolving institutions. WIDER Conference Paper, United Nations University, Finland.

Zhang, L-Y. (1999). Chinese central-provincial fiscal relationship, budgetary decline and the impact of the 1994 fiscal reform: An evaluation. The China Quarterly, 157, pp.115-141.

Zhang, T., and Zou, H.-F. (1998). Fiscal decentralization, public spending, and economic growth in China. Journal of Public Economics, 67(2), pp.221-240.

Zhang, X. (2006). Fiscal decentralization and political centralization in China: Implications for growth and inequality. WIDER Research Paper No. 2006/93, United Nations University, Finland.

Zhao, X. B., and Zhang, L. (1999). Decentralization reforms and regionalism in China: A review. International Regional Science Review, 22(3), pp.251-281.

\section{Appendix: China's regions}

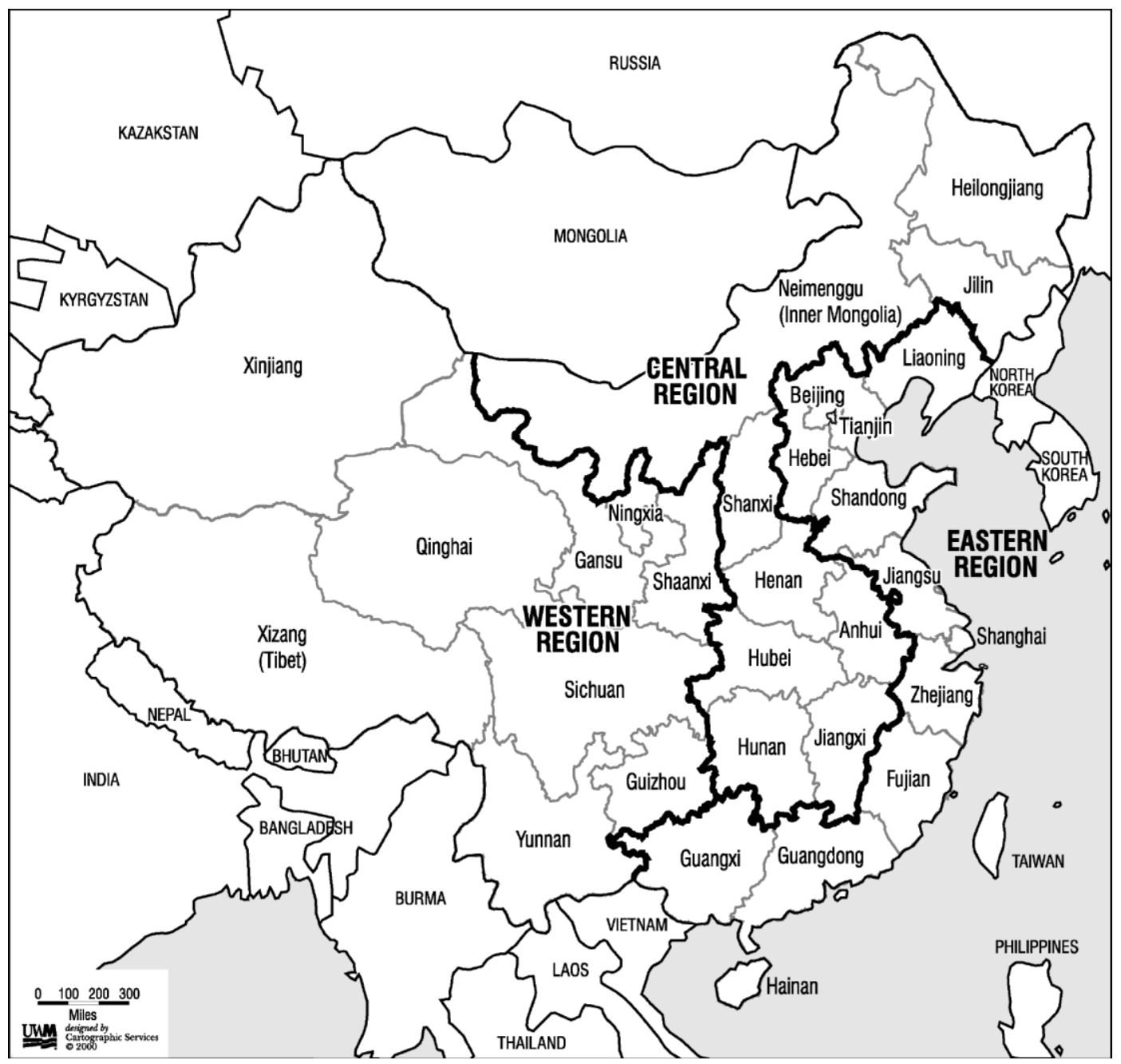

